ENL-8487

D293 007321

\title{
Advanced Metering Techniques
}

R. F. Szydlowski

January 1993

Prepared for

the U.S. Department of Energy

Federal Energy Management Program

under Contract DE-ACO6-76RLO 1830

Pacific Northwest Laboratory 


\section{Preface}

The goal of the U.S. Department of Energy Federal Energy Management Program (FEMP) is to facilitate energy-efficiency improvements at federal facilities. This is accomplished by a balanced program of technology development, facility assessment, and use of cost-sharing procurement mechanisms. Technology development focuses upon the tools and procedures used to identify and evaluate efficiency improvements. For facility assessment, FEMP provides metering equipment and trained analysts to federal agencies exhibiting a commitment to improve energy-use efficiency. To assist in implementing energy-efficiency measures, FEMP helps federal agencies with identifying efficiency opportunities and in implementing energyefficiency and demand-side management programs at federal sites.

As the lead latoratory for FEMP, Pacific Northwest Laboratory (PNL) provides technical assistance to federal agencies to better understand and characterize energy systems. The U.S. Army Forces Command (FORSCOM) has tasked PNL to provide technical assistance to sharacterize and modernize energy systems at FORSCOM installations.

As part of that technical assistance, PNL performed an in-depth examination of automatic meter-reading system technologies currently available. The operating characteristics and relative merits of all the major systems were reviewed in the context of applicability to federal installations. That review is documented in this report. 


\section{Summary}

Utility company metering of electricity, gas, and water for billing purposes typically uses technologies that were developed a hundred years ago. And, as was the practice at its first commercial introduction, the overwhelming majority of the meters are still read visually and the readings recorded manually in a meter book by a person who walks a route. Advanced metering systems provide an opportunity to totally redesign conventional revenue billing, load evaluation and survey, and customer relations processes. Advanced meters include both expanded metering features, such as time-of-use rates and demand-profile recording, and communications technologies that allow 1) remote electronic meter reading, 2) mobile radio meter reading, and 3) fully automatic meter reading (AMR) systems.

Handheld computers, with remote meter reading and remote electronic meter reading, introduced automation into the meter reading and billing process, plus access to hard-to-read meters. But these systems still require a person to physically contact each meter or a receptacle linked to a nearby meter.

Mobile radio systems reduce labor requirements and reading errors by using low-power radio to communicate directly between a meter and a handheld or van-based computer. Mobile radio systems have the largest number of installed units and enjoy the highest acceptance by utilities. However, they are limited with regard to meter-reading frequency (scheduled monthly reads only) and other advanced metering features.

Dial-in telephone system meters are programmed to periodically call the central station by using a shared customer telephone line. The central station cannot contact the meter without ringing the customer's telephone. This system raises some privacy issues and limits the meterreading frequency and other advanced metering features requiring communications initiated by the central station.

Conventional dial-out telephone systems with dedicated leased telephone lines are the least expensive form of an unrestricted full-time two-way communications AMR system for a limited number of special customers. Special customers include those with very hard-to-read meters or unique metering requirements (large customers). Some dedicated lines can be avoided by using automatic line-share switches, which connect a shared line to a meter without ringing the customer's telephone.

Expansion to a large set of customers will require no-ring dial-out telephone systems. The no-ring dial-out telephone system is dependent on the cooperation of the telephone operating company for access, installation of special equipment at the telephone switch station, and reasonabie tariffs. Telephone number management has proven to be a difficult problem for large systems. 
Distribution line carrier systems perform well for high-density electric metering and demandside management (DSM) load control. These systems are independent of the telephone companies and radio frequency availability problems. But they may be prohibitively expensive for very low-density metering and may be unavailable for some gas and water metering.

Long-range radio, configured as packet transceivers, cellular nodes, or central broadcast towers, can offer the largest range of near real-time meter reading for large metering systems. This is the only technology that can provide unrestricted high-speed two-way communication with each individual meter of a large system, which may be necessary for additional services such as security, energy management, or customer information. However, the radio equipment required for complete coverage of a large service territory, and the maintenance thereof, is the most expensive of all the systems.

This report presents the operating characteristics and relative merits of all the major AMR system technologies in use today. Each technology excels in one or more areas, but each also has a technical weakness or high cost. There is no single "best" AMR system for all applications. Selection of the most appropriate AMR system will require investigation of the characteristics of the service territory to be metered, the number and type of customers to be metered, and the metering services required.

To exemplify how a most appropriate AMR technology is selected, a typical federal facility with two different AMR system requirements is described.

Case 1 requires a minimum AMR system configuration, with a relatively small number (100 to 500) of basic monthly-read meters. A dial-in telephone technology is probably the most appropriate $A M R$ system for this case. The dial-in telephone technology has the lowest first cost for equipment and requires the least equipment maintenance, while allowing for sophisticated metering. The dial-in system can be supplemented with a limited dial-out system using dedicated telephone lines for special meters that require frequent and/or unscheduled reads. The dial-out meters may be able to share a voice line using a special switch that allows calls to the meter without ringing the customer's telephone.

Case 2 requires a full AM system implementation, with a large number (1000 to 5000) of meters and DSM load control features. For this case, a distribution line carrier (DLC) system using the zero-crossing technique is probably the most appropriate AMR system. The DLC technology has a high first cost for equipment, but provides a simple growth path for a large number of meters. The zero-crossing technique minimizes equipment maintenance because the only communications equipment is located in the electrical substations. DSM load control of electrical devices, with full two-way communications and tamper detection, is easily implemented. Meters that do not have access to electric power, and therefore communications via the DLC, can be supplemented with dial-out meters. 
A potential alternative AMR technology for Case 2 is a recently announced packet radio design that communicates directly between the meter and the local transceiver via radio instead of the power line carrier required by existing systems.

One special consideration for federal facilities is that most buildings do not have any installed metering and were not designed for the installation of metering. Most AMR systems automatically assume that a utility has existing metering that will be adapted. The installation of basic metering equipment that is compatible with an AMR system will be a significant additional cost.

The full power of AMR systems will be realized with the installation of continuous realtime communications and electronics that allows a wider range of metering and control functions. More sophisticated metering accommodates a variety of rate structures and provides more detailed load evaluation and power quality (volt, ampere, power factor) information--in real time. Control functions allow intelligent DSM load control with feedback (two-way communications). Use of these new features, which were not traditionally part of meter reading and previously required dedicated and expensive systems, will justify AMR system costs. 


\section{Acknowledgments}

The author would like to thank Richard Rundus, U.S. Army Construction Engineering Research Laboratory, for providing preliminary information regarding the state of the automatic meter reading industry. Appreciation is extended to PNL staff whose efforts supported this report: Mark Halverson for collecting and summarizing a large quantity of manufacturers' literature, and Andrea Currie for final editing. 


\section{Contents}

Preface $\ldots \ldots \ldots \ldots \ldots \ldots \ldots \ldots \ldots \ldots \ldots \ldots \ldots \ldots \ldots \ldots \ldots \ldots \ldots \ldots \ldots$

Summary $\ldots \ldots \ldots \ldots \ldots \ldots \ldots \ldots \ldots \ldots \ldots \ldots \ldots \ldots \ldots \ldots \ldots \ldots$

Acknowledgments $\ldots \ldots \ldots \ldots \ldots \ldots \ldots \ldots \ldots \ldots \ldots \ldots \ldots \ldots \ldots \ldots \ldots$ viii

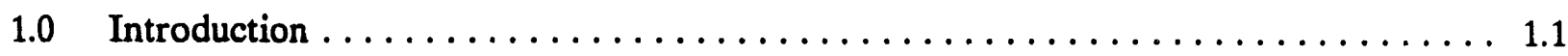

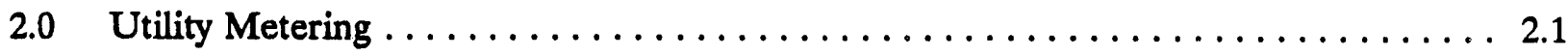

2.1 Electricity Meters $\ldots \ldots \ldots \ldots \ldots \ldots \ldots \ldots \ldots \ldots \ldots \ldots \ldots \ldots \ldots \ldots \ldots$

2.1.1 Modified Spinning Disk Meters $\ldots \ldots \ldots \ldots \ldots \ldots \ldots \ldots \ldots \ldots$

2.1.2 Solid-State Electronic Meters $\ldots \ldots \ldots \ldots \ldots \ldots \ldots \ldots \ldots \ldots .2 . \ldots \ldots$

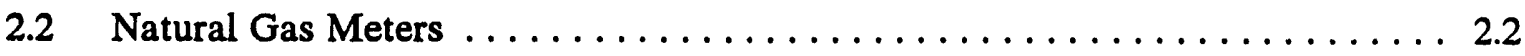

2.2.1 Modified Conventional Meters $\ldots \ldots \ldots \ldots \ldots \ldots \ldots \ldots \ldots . . \ldots \ldots$

2.2.2 Future Designs $\ldots \ldots \ldots \ldots \ldots \ldots \ldots \ldots \ldots \ldots \ldots \ldots \ldots \ldots$

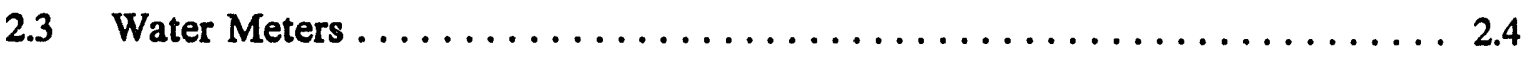

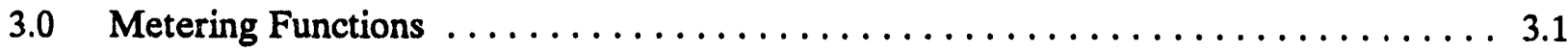

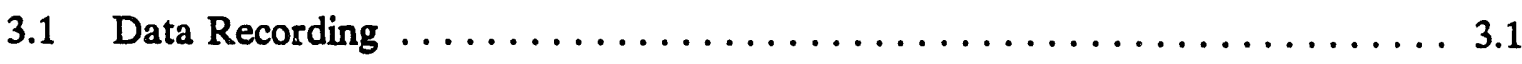

3.1.1 Total Consumption $\ldots \ldots \ldots \ldots \ldots \ldots \ldots \ldots \ldots \ldots \ldots \ldots \ldots$

3.1.2 Time-of-Use Metering $\ldots \ldots \ldots \ldots \ldots \ldots \ldots \ldots \ldots \ldots \ldots \ldots \ldots$

3.1.3 Peak Demand Metering $\ldots \ldots \ldots \ldots \ldots \ldots \ldots \ldots \ldots \ldots \ldots \ldots$

3.1.4 Load Survey (Profile or Time-Series Data) . . . . . . . . . . 3.1

3.1.5 Power Outage Recording $\ldots \ldots \ldots \ldots \ldots \ldots \ldots \ldots \ldots \ldots \ldots$ 


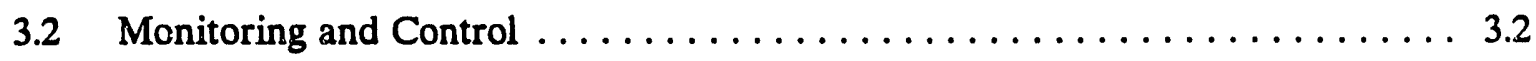

3.2.1 Real-Time Power Outage Reporting $\ldots \ldots \ldots \ldots \ldots \ldots \ldots \ldots .2$

3.2.2 Leak Detection $\ldots \ldots \ldots \ldots \ldots \ldots \ldots \ldots \ldots \ldots \ldots \ldots \ldots, 3.2$

3.2.3 Tamper Detection $\ldots \ldots \ldots \ldots \ldots \ldots \ldots \ldots \ldots \ldots \ldots \ldots .2$

3.2.4 Remote Service Disconnect/Reconnect $\ldots \ldots \ldots \ldots \ldots \ldots \ldots .2$

3.2.5 Load Control $\ldots \ldots \ldots \ldots \ldots \ldots \ldots \ldots \ldots \ldots \ldots \ldots \ldots .2$

3.2.6 Load Scheduling $\ldots \ldots \ldots \ldots \ldots \ldots \ldots \ldots \ldots \ldots \ldots \ldots \ldots \ldots$

3.3 Customer Interface $\ldots \ldots \ldots \ldots \ldots \ldots \ldots \ldots \ldots \ldots \ldots \ldots \ldots, \ldots .3$

3.3.1 Energy Management System Home Interface $\ldots \ldots \ldots \ldots \ldots \ldots . .3$

3.3.2 Customer Billing Functions $\ldots \ldots \ldots \ldots \ldots \ldots \ldots \ldots \ldots \ldots, 3.3$

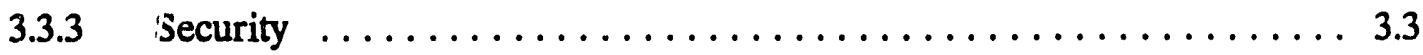

4.0 Communications Techniques $\ldots \ldots \ldots \ldots \ldots \ldots \ldots \ldots \ldots \ldots \ldots \ldots \ldots . . \ldots \ldots$

4.1 Remote Meter Reading $\ldots \ldots \ldots \ldots \ldots \ldots \ldots \ldots \ldots \ldots \ldots \ldots \ldots .1$

4.2 Mobile Radio Meter Reading $\ldots \ldots \ldots \ldots \ldots \ldots \ldots \ldots \ldots \ldots \ldots . \ldots \ldots \ldots$

4.3 Telephone-Based Communications $\ldots \ldots \ldots \ldots \ldots \ldots \ldots \ldots \ldots \ldots .2$

4.3.1 Dial-In Telephone $\ldots \ldots \ldots \ldots \ldots \ldots \ldots \ldots \ldots \ldots \ldots \ldots . .4 .3$

4.3.2 Dial-Out Telephone: No-Ring $\ldots \ldots \ldots \ldots \ldots \ldots \ldots \ldots \ldots .4 .4$

4.3.3 Dial-Out Telephone: Convertional $\ldots \ldots \ldots \ldots \ldots \ldots \ldots \ldots \ldots .6$

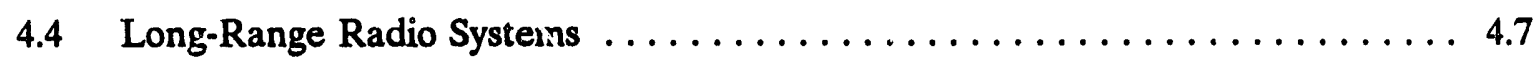

4.4.1 Amplitude-Modulation (AM) Radio $\ldots \ldots \ldots \ldots \ldots \ldots \ldots \ldots .4 .7$

4.4.2 Frequency-Modulation (FM) Radio $\ldots \ldots \ldots \ldots \ldots \ldots \ldots \ldots .8$

4.4.3 Ultra-High-Frequency (UHF) Radio $\ldots \ldots \ldots \ldots \ldots \ldots \ldots \ldots .8$ 
4.4.4 $900-\mathrm{MHz}$ Radio $\ldots \ldots \ldots \ldots \ldots \ldots \ldots \ldots \ldots \ldots \ldots . \ldots \ldots$

4.4.5 $900-\mathrm{MHz}$ Spread-Spectrum Radio . . . . . . . . . . . . 4.9

4.5 Electric Distribution Power Line Carrier and Zero Crossing . . . . . . . 4.10

4.6 Hybrid AMR Systems $\ldots \ldots \ldots \ldots \ldots \ldots \ldots \ldots \ldots \ldots \ldots \ldots \ldots \ldots \ldots \ldots$

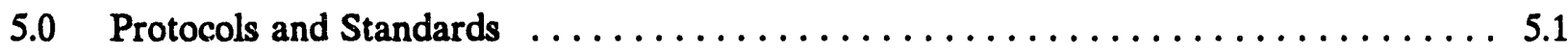

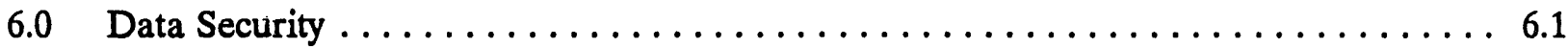

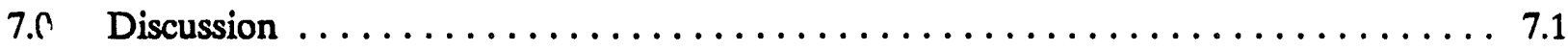

8.0 Selecting an Automatic Meter-Reading System $\ldots \ldots \ldots \ldots \ldots \ldots \ldots \ldots \ldots$

8.1. AMR System Selection Criteria $\ldots \ldots \ldots \ldots \ldots \ldots \ldots \ldots \ldots \ldots \ldots \ldots . \ldots \ldots$

8.2 System Selection Case Studies $\ldots \ldots \ldots \ldots \ldots \ldots \ldots \ldots \ldots \ldots \ldots \ldots .2$

8.2.1 Case 1 Specitications and AMR Technology Selection $\ldots \ldots \ldots \ldots . .2$

8.2.2 Case 2 Specifications and AMR Technolcgy Selection $\ldots \ldots \ldots \ldots . . .8$

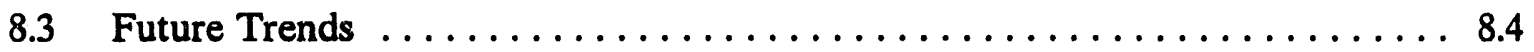

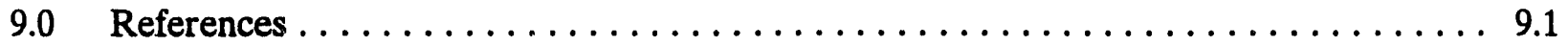

Appendix - AMR Equipment and Manufacturers $\ldots \ldots \ldots \ldots \ldots \ldots \ldots \ldots \ldots$ 


\section{Figure}

1.1 Migration from Manual to Automatic Meter Reading $\ldots \ldots \ldots \ldots \ldots \ldots \ldots \ldots$

\section{Tables}

4.1 Relative Merits of Mobile Radio Systems $\ldots \ldots \ldots \ldots \ldots \ldots \ldots \ldots \ldots \ldots \ldots \ldots$

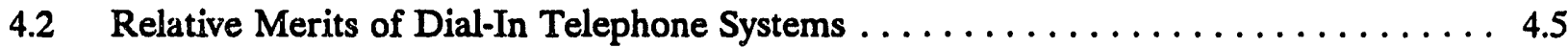

4.3 Relative Merits of Dial-Out Telephone Systems $\ldots \ldots \ldots \ldots \ldots \ldots \ldots \ldots$

4.4 Relative Merits of $900-\mathrm{MHz}$ Cellular Radio Systems $\ldots \ldots \ldots \ldots \ldots \ldots \ldots \ldots$

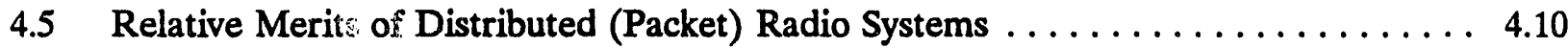

4.6 Relative Merits of Distribution Line Carrier Systems $\ldots \ldots \ldots \ldots \ldots \ldots \ldots \ldots . \ldots 4$

7.1 AMR Technology Screening Matrix: Meter Reading Alternatives $\ldots \ldots \ldots \ldots .2$

7.2 Number of Installed Metering Units Versus AMR Technology $\ldots \ldots \ldots \ldots \ldots \ldots .4$

8.1 AMR System Assumptions Common to Both Case 1 and Case $2 \ldots \ldots \ldots$

8.2 Special AMR System Assumptions for Case $1 \ldots \ldots \ldots \ldots \ldots \ldots \ldots \ldots \ldots$

8.3 Special AMR System Assumptions for Case $2 \ldots \ldots \ldots \ldots \ldots \ldots \ldots \ldots \ldots \ldots$

A.1 Meter Reading Equipment Manufacturers $\ldots \ldots \ldots \ldots \ldots \ldots \ldots \ldots \ldots \ldots$ A.2 


\subsection{Introduction}

Utility company metering of electricity, gas, and water for billing purposes typically uses technologies that were developed a hundred years ago. And, as was the practice when they were first commercially introduced, most of the meters are still read visually and their readings recorded by hand in a meter book by a person who walks a route.

On the positive side, conventional metering equipment is time- and field-proven, with welldefined long-term maintenance and calibration characteristics and extremely low unit costs. Unit costs of $\$ 20$ to $\$ 30$ for standard residential electric, gas, and water meters are a result of decades of high-volume production and low development costs.

Although the electric utility industry often cites the average manual meter-reading costs as a very inexpensive $\$ 0.50$ per read (monthly), reading costs for hard-to-read (inaccessible or remote rural) meters are clearly much higher. Although the average meter-reading cost for Northeast Utilities was $\$ 1.04$ per read, the hard-to-read meters cost as much as $\$ 5.50$ per read (Scott 1992). A survey of 113 investor-owned utilities showed that hard-to-read meters comprise $11 \%$ of the totai residential meters but $60 \%$ of the meter-reading cost. And very hard-to-read meters comprise $4 \%$ of the total accounts but $25 \%$ of the annual meter-reading cost.

One representation of the hierarchy of metering techniques is graphically presented in Figure 1.1 (Dulabaum 1992). Many utilities considered these five metering categories as a very practical migration strategy for moving from handheld computers to fully automatic meter reading (AMR).

The five metering categories can be described as follows:

- manual meter reading - A meter reader uses a route book and manually records the meter readings. A clerk manually calculates consumption and manually prepares the bill. Computers have been introduced to accelerate the basic billing process and reduce clerical errors, but the basic process has not changed in a hundred years.

- handheld computers - Meter readers enter a visually-read meter reading directly into a handheld device. Although the handheld device does not automatically obtain the reading, this simple step dramatically improves clerical accuracy in the billing stages. Some handheld devices are "smart" enough to display routing and special meter information (e.g., under deck, beware of bad dog) and to notify the meter reader if the new reading is out of range, indicating a possible error.

Handheld computers are often complemented by reading a second register or receptacle linked to a nearby meter, called remote meter reading (RMR). 'T his is particularly 


\section{Hierarchy of Meter Reading Technology}

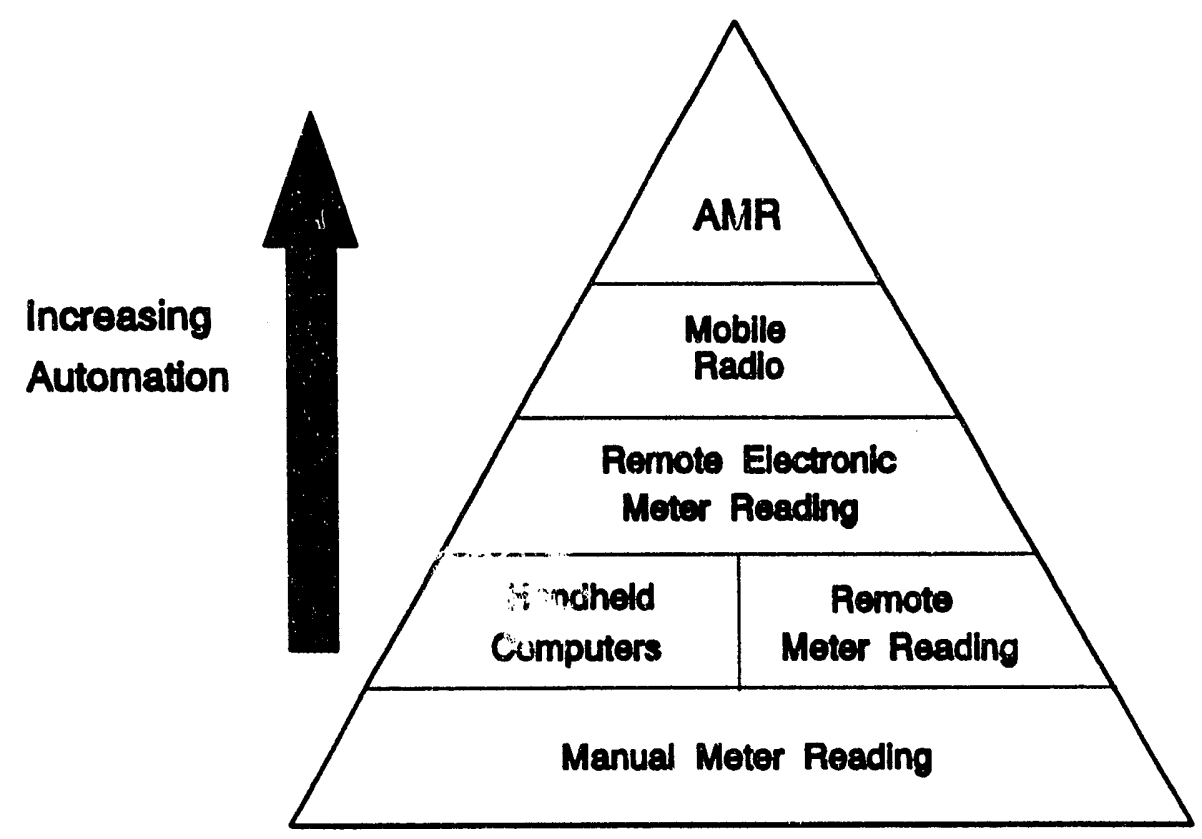

Figure 1.1. Migration from Manual to Automatic Meter Reading.

important for meters that are physically hard to access because they are installed in basements, behind locked gates, or near bad dogs.

- remote electronic meter reading - When $\mathrm{RMR}$ is combined with an electronic data transfer technology, the meter can be automatically read by the handheld device. Remote electronic meter reading still requires physical contact between the handheld device and the meter or a receptacle linked to a nearby meter, but it completely eliminates the errors associated with a visual reading and manual data entry.

- mobile radio meter reading - The meter reader need only come within close proximity of the customer premises. Radio frequency communication is used to send a signal to "wake up" the transmitter located at the meter, which will then send its reading to the receiver. The receiver can be either a vehicle-based computer or a handheld device.

- automatic meter reading ( $A M R)$ - Fully automatic meter reading refers to requesting and receiving meter-reaciing information from a central location via telephone line, radio 
frequency, power line carrier (PLC), or cable television. All meter reads are automatically handled by a computerized system instead of a person visiting each meter location.

Advanced metering techniques provide an opportunity to totally redesign conventional revenue billing, load evaluation and survey, and customer relations processes. Remote and fully automatic metei-reading systems can substantially reduce labor costs and accelerate the revenue billing cycle. The advantages of advanced metering include

- reduction or complete elimination of labor requirements for manual meter reads

- improved meter-reading accuracy, which reduces labor requirements for meter re-reads

- electronic access to hard-to-read meters

- elimination of estimated readings based on bimonthly/quarterly/yearly meter readings

- collection (f profile and load survey information (monthly, daily, or near real-time)

- implementation of innovative rate structures (e.g., time-of-use, real-time pricing, interruptible rates, or demand charges).

- easy adaptation to dispatchable rate structures

- improved customer service and feedback

- meter-tampering detection and lost revenue reduction

- leak detection in water and gas systems

- outage detection assistance

- load control and scheduling.

Compared to conventional meters, advanced meters include both advanced metering features and communications technologies. Advanced communications technologies make possible systems that enable 1) remote electronic meter reading, 2) off-site meter reading, and 3) fully automatic meter reading.

In this report, information on meter-reading systems is summarized. The capabilities of advanced metering systems are discussed, and the opportunities they can provide are described. 


\subsection{Utility Metering}

The basic electric, gas, and water utility meters and their capabilities are summarized in this section. Some of the advanced metering equipment that is commercially available is described also. Many of the advanced metering functions are currently available thorough addon equipment and multiple systems. Advanced metering equipment will make is possible to consolidate these functions into one common system, which can reduce equipment and operating costs.

\subsection{Electricity Meters}

Electric power is typically measured using the standard kilowatt-hour (kWh) electric power meter, which is found on about 100 million residences and commercial buildings in the Trnited States. Utility companies purchase these meters for $\$ 20$ to $\$ 30$ each. The standard sining disk $\mathbf{k W h}$ meter technology was devel.sped a hundred years ago. Most of these meters are still read visually and the readings recorded manually in a meter book by a person who walks a route.

The basic $\mathrm{kWh}$ meter measures accumulated electrical energy (kilowatt-hours). The kilowati-hour is of prime importance because it relates directly to the amount of electricity delivered, and therefore billed, to the customer. Although many large commercial cus omers are billed for kilowatt (kW) demand (Imaximum power) in addition to accumulated energy (kWh), that is rarely true for residential customers. Some electric utilities are also introducing time-ofuse (TOU) rates. Under this type of rate structure, customers are charged higher rates during peak demand times than they are during off-peak times. The basic $\mathrm{kWh}$ meter measures and displays accumulated energy ( $\mathrm{kWh}$ ) but not instantaneous power or time-ot-day use.

A modified basic $\mathrm{kWh}$ meter can be used to meassure, and record, demand interval power. A timer is included to set the duration of the demand interval. Such a meter always integrates demand over a preset time interval $(15,30$, or 60 minutes) and does not record true instantaneous demand.

Electric utilities also charge some large commercial and industrial customers according to power factor (PF) or reactive power ( $Q$ ). Measurement of $P F$ or $Q$ requires a second basic meter that has been modified to measure reactive power instead of $\mathrm{kWh}$.

\subsubsection{Modified Spinning Disk Meters}

The first step toward advanced electric meters is based on a standard spinning disk $\mathrm{kWh}$ meter combined with some type of pulse initiator and/or encoding device, resulting in an electromechanical meter. Solid-state electronics are used for monitoring and storing metering 
data, including information on both billing (total accumulated $\mathrm{kWh} ; 15-, 30-$, or $60-$ minute demand; and TCU) and load survey (1-minute to daily interval profiles). These meters usually have industry stanuard optical communications ports (typically compatible with Opticom ${ }^{\mathrm{TM}}$ ) and/or RS232 computer communications ports. The most advanced electromechanical meter systems include sophisticated communications capabilities, such as power line carrier, telephone modems, or ratio transceivers, and still fit under the glass of a standard $\mathrm{kWh}$ meter. Use of the appropriate interface device and handheld computer enable a meter reader to download large amounts cif cata 'rom the meter directly into the handheld device. In addition, many of these meters can be reprogrammed by means of the same handheld computer. At a retrofit cost of $\$ 100$ to $\$ 250$ ror meter, this may be the least expensive electronic metering option for existing meters.

\subsubsection{Solid-State Electronic Meters}

The second step toward advanced electric meters completely replaces the mechanical components of standard spinning disk kWh meters with solid-state electronics. Such meters were first introduced in the 1970s. Most use transducers to convert the service current and voltage into low-voltage analog signals and/or pulses. Electronic circuits convert the analog signals into digital values, which are used to calculate a variety of electrical parameters, such as kilowatts, watts, reactive energy, power factor, volts, or amperes. The solid-state electric power meter is capable of measuring much more than is a retrofitted standard mechanical meter. Solid-state meters have become sophisticated and can measure and store huge amounts of information, including selected electrical parameters, load survey data (1-minute to daily interval profiles) about any electrical parameters, TOU data, and total accumulated values.

Like the electromechanical meters, solid-state meters usually have industry standard optical communications ports (typically compatible with Opticom $^{\mathrm{TM}}$ ) and/or RS232 computer communications ports. Use of the appropriate interface device and handheld computer enables a meter reader to download large amounts of data from the meter directly into the handheld co:nputer. The meters can be reprogrammed by the same handheld computer. In addition, most of these meters include Supervisory Control and Data Acquisition (SCADA), Distribution Automation (DA), or AMR communications equipment, such as a radio transponder, power line carrier, or telephone modem circuit. These meters tend to ue used in substations and on particularly important industrial loads. But, at $\$ 250$ to $\$ 1500$ each, they are too expensive for most mass AMR applications.

\subsection{Natural Gas Meters}

Gas-metering techniques can be divided into two basic types. The first is displacement meters, which measure the quantity of gas that actually flows through the meter. The second type is known as rate of flow meters. Such meters measure the instantaneous rate of flow of gas through the meter. These meters usually have "totalizers," which enable them to display total 
volume of flow instead of rate of flow, which is equivalent to the displacement meters. The displacemunt meters are more accurate for measuring a very wide range of flow rates (such as pilot lights to full furnace operation), but are very expensive in 'urge sizes. Similar to standard electric meters, there are millions of gas customers with standard bellows or diaphragm displacement types of residential gas meters, which cost about $\$ 20$ to $\$ 30$ each.

\subsubsection{Modified Conventional Meters}

Advanced gau meters are based on the addition of electronics that use the mechanical dials found on a typical gas meter to either generate pulses or encode the dials. A variety of techniques have been used to generate pulses that are proportional to the amount of gas metered, including reed switches, hall effect, Wiegand effect, piezoelectric effect, and optical sensors. Once converied to a pulse, metering data are monitored and stored using solid-state electronics in a manner similar to that of the electromechanical electric meters.

Meter encoding devices transmit a digital code that corresponds to the actual reading of the dials on the face of the meter. Most encoding devices rely on some means of scanning the meter dials and then electronically converting the position of the dials into a meter reading. The major advantage of the encoding devices is that they need to function only during the time an actual meter reading is made, which reduces operating power requirements. A pulse initiator device must be continuously powered and is subject to noise and interference, which could be cumulative in nature, between readings. Encoding devices are typically used for simple meier readings, not for load survey (profile or time series), TOU, or demand data collection.

Unlike electric merers, where sufficient power is available within the meter for any reasonable electronic application, most AMR systems for gas and water meters are usually battery-powered. This restricts the appropriate electronic techniques to those that require very little power. For example, meter dial indicators can be monitored by optical scanning techniques, but this is not done as often as with electric meters because this optical technique normally requires more power than can be conveniently supplied with a battery. One encoding device avoids batteries altogether by using low-power electronics and magnetic coupling with the meter's output shaft.

\subsubsection{Future Designs}

Like electric power meters, the second step toward advanced gas meters completely replaces the mechanical components of standard displacement gas meters with solid-state electronics. British Gas has begun field trials of two new ultrasonic meter designs that are modular, compact, efficient, contain electronics that can operate for 10 years on batteries, and contain a customer control switch and electronic interface. This will be the first domestic gas meter without any internal moving parts. 


\subsection{Water Meters}

Water metering techniques parallel those for natural gas. The most common type of billing water meter is the positive displacement meter using either an oscillating piston or nutating disk. Similar to standard electric meters, millions of water customers have standard water meters that cost about $\$ 20$ each.

Advanced water meter techniques are identical to those of the advanced natural gas meters discussed in Section 2.2.1. 


\subsection{Metering Functions}

Some of the metering functions available through advanced metering techniques are described in this section. Many of the functions are currently available through add-on equipment and multiple systems. Advanced metering equipment would make it possible to consolidate these functions into one common system, which should reduce equipment and operating costs.

\subsection{Data Recording}

Advanced meters can duplicate the conventional metering function of recording total consumption, plus offer enhanced functions such as time-of-use, peak demand, load survey, and power outage recording. For electric metering, advanced meters may also include recording of : other electric characteristics, such as voltage, current, and power factor.

\subsubsection{Total Consumption}

This is the most basic data recording function, which duplicates the standard kilowatt-hour of electricity (kWh), hundred cubic feet volume (CCF) of gas, or gallons (gal) of water consumed between meter readings.

\subsubsection{Time-of-Use Metering}

Different rates can be charged for on-peak and off-peak time periods by accumulating the total consumption during operator-defined time windows. ?he time windows may vary during both time of day and weekday/weekend/holiday.

\subsubsection{Peak Demand Metering}

Billing of many larger commercial and industrial customers is based on total consumption and the highest 15-, 30-, or 60-minute demand during the billing period. The peak demand may be reported as a single highest value, highest four values, or highest value during each hour (all peak demand values must be accompanied by an associated time stamp).

\subsubsection{Load Survey (Profile or Time-Series Data)}

Energy consumption and conservation impact studies, as well as more complex analysis of system loading, require more detailed demand data. A load survey provides periodic consumption or demand data (in time increments of $1,5,15,30$, or 60 minutes). 


\subsubsection{Power Outage Recording}

Recording the time and duration of each power outage can help evaluate the quality of electric power service available to various customer areas.

\subsection{Monitoring and Control}

A two-way communication link between the central station and customer site provides the opportunity for integrating some other utility functions into the metering functions. Meters can be programmed to detect and report by exception (e.g., report only when a fault is detected) for power outage, leak detection, and tamper detection. The meter can also dispatch control functions, such as remote service disconnect/reconnect, demand-side management (DSM) load control, and load scheduling.

\subsubsection{Real-Time Power Outage Reporting}

Real-time reporting of power outages can help the electric utility identify the location and scope of a problem before sending service crews in the field.

\subsubsection{Leak Detection}

Continuous monitoring of gas or water usage can be used to detect leaks.

\subsubsection{Tamper Detection}

Meter tampering by customers leads to a significant revenue loss. A variety of techniques can be used to identify meter tampering. These include power outage profiles, reverse current flow, and tilting and opening the meter.

\subsubsection{Remotc 3ervice Disconnect/Reconnect}

The electric utility can connect and disconnect service without an on-site visit. This is particularly important with high turnover areas and chronically late payment customers.

\subsubsection{Load Control}

Load control includes DSM control functions such as air conditioner and water heater loadshedding. The DSM load control could be triggered by a fixed algorithm operating independently or real-time central station control. 


\subsubsection{Load Scheduling}

This includes scheduled start and stop of equipment to minimize or shift load to take maximum advantage of the demand and time-of-use billing rate structures.

\subsection{Customer Interface}

A two-way communication link between the central station and customer site also provides the opportunity for offering some totally new utility services via the advanced meter. Services include utilities consumption and billing information made available through either a home energy management system or direct displays, and a security systems communication link.

\subsubsection{Energy Management System Home Interface}

The home energy management system (EMS) is an evolving area, with a feature list that is constantly expanding. A vital part of every EMS is measurement and display of utilities consumption. Advanced meters can provide this information directly to the EMS.

\subsubsection{Customer Billing Functions}

Customer billing functions can vary between simple displays of instantaneous and cumulative consumption and cost information, and full interaction with the utility company billing system (purchase energy as needed).

\subsubsection{Security}

A large distributed communication system that is useful for real-time AMR is also viable for security systems applications. The security system may be a full stand-alone installation that uses the AMR system as a communications link, or a few alarm functions that are an integral part of the AMR system. 


\subsection{Communications Techniques}

Selection of an advanced metering system is based on the data recording, monitoring and control, customer interface, and communications capabilities. However, the communications techniques may limit the data recording, monitoring and control, and customer interface options available. In addition, the communications technique cost-per-meter varies dramatically depending on meter density and function. Therefore, the communications technique is the main determinant in the selection of any advanced metering technique. The more common communications techniques and their relative advantages and disadvantages are summarized in the following sections.

\subsection{Remote Meter Reading}

Inaccessible meters are common. An early solution was to have a remote display or data transfer link hard-wired to the meter and placed in an accessible location. Because water meters had to be located where they would not freeze in northern climates, typically in a basement, the water meter companies were the first to develop remote meter reading. Early approaches were to install an encoder or pulse initiator connected through hard wires to a second (remote) display. More recent technology advances have led to installation of remote electronic data links that allow direct downloading of the meter reading into a handheld meter reader.

\subsection{Mobile Radio Meter Reading}

Mobile radio systems used as an off-site meter reading technique are deployed more often than any other communications system in automatic meter reading. Mobile radio, which is used for simply collecting meter reads, is not as versatile as full-function, two-way communications systems, which provide on-demand or real-time data and load-shedding DSM. However, mobile radio systems are relatively low-cost and provide quick meter read times.

Mobile radio systems can be either vehicle-based or handheld. The radio transceivers are low-power, short-range (1,000 feet) and do not require Federal Communications Commission (FCC) licenses. The vehicle-based systems usually use a van outfitted with a personal computer, transmitter and receiving equipment, and appropriate software. Each meter point is retrofitted with an encoder and transmitter/receiver, typically installed inside the meter. Costs include a van, $\$ 50,000$ for the van's equipment, and $\$ 150$ per meter.

The data collection process requires loading the meter addresses into the personal computer and driving a predetermined course at $35 \mathrm{mph}$. The van sends out a radio frequency signal ranging from 1,000 to 1,500 feet to wake up the meters. The meter electronics respond by sending its address and meter reading. At the end of the route, the data is transmitted to the 
utility's main computer. Meter reading rates of up to 3,000 meters/hour are claimed for dense residential urban areas.

Traditional handheld electronic meter reader manufacturers offer an upgrade to the meter that will enable handheld computers to read the meter via radio frequency. This allows traditional walk-up reading of readily-accessible meters mixed with mobile radio reading of those troublesome hard-to-read meters. Table 4.1 lists the relative merits of off-site meter reading systems.

Table 4.1. Relative Merits of Mobile Radio Systems

\begin{tabular}{|c|c|}
\hline Advantages & Disadvantages \\
\hline $\begin{array}{l}\text { Least: expensive of all AMR system } \\
\text { types. } \\
\text { - Simplest to install of all AMR system } \\
\text { types. } \\
\text { - Convenient for all utilities. } \\
\text { - Battery-driven: no connection to other } \\
\text { networks required (of importance to } \\
\text { some gas utilities). } \\
\text { - Intelligence is decentralized, less chance } \\
\text { for total system shutdown. } \\
\text { Some systems are extensively field- } \\
\text { proven. }\end{array}$ & $\begin{array}{l}\text { Not suitable for real-time data return } \\
\text { (data collection available only when } \\
\text { communications equipment is in area). } \\
\text { Not usable for transmission of } \\
\text { spontaneous alarm messages (report by } \\
\text { exception messages). } \\
\text { Battery replacement may be a } \\
\text { maintenance problem. }\end{array}$ \\
\hline
\end{tabular}

\subsection{Telephone-Based Communications}

AMR communications networks based on the existing telephone system are very attractive, particularly for remote and low-density installation. The existing telephone system already provides two-way communications to nearly all residential, commercial, and industrial facilities. Cellular telephone equipment costs are falling rapidly; this equipment could be used at many of the sites where standard telephone service is not available.

Large-scale telephone-line-based installations of AMR systems must make use of existing customer lines. Installation of a large number of dedicated telephone lines is prohibitively costly and may simply be impossible because of limited "extra" lines available in the customer area. 
Because the AMR system must share the customer telephone line, any data communications should be totally transparent to the customer. The AMR system must be capable of determining if the telephone line is already in use as it starts to initiate a call, and if necessary, delay its call until the line is free. It should also provide a priority interrupt feature, which will sense a telephone going off-hook during a data call, hang up the metering equipment, and provide a dial tone, all within a few seconds. It is critical that AMR system-related communications do not interfere with normal voice operation, do not interrupt normal voice traffic, and do not cause the telephone to ring.

Although telephone-based communications systems are relatively inexpensive, there are some serious issues that must be addressed. Many customers fear that "big brother" (the utility) will be able to listen in on their private telephone conversations. Failure to carefully develop a good public relations program that builds customer confidence in the utility's benevolent use of the telephone system will almost certainly result in a failed program.

Customers also fear that their private telephone line will not be available when they need it, such as during an emergency. Because most metering equipment will transmit data for as little as 1 minute per month (monhly totals) up to 10 minutes per day (detailed daily profile recording), in the middle of the night, there is little chance of interference. However, one solution is the priority interrupt feature described above.

Telephone number management seems simple, but has proven to be a very real administrative problem. AMR system communications can be blocked by customers who change their telephone numbers and customers who move away from a site and discontinue telephone service. Recent telephone-based AMR system experience has shown that for large installations, this telephone number tracking problem may be prohibitively time-consuming and expensive.

Integration of simultaneous voice and data communications, called Integrated Services Digital Network (ISDN), is scheduled for many local telephone companies within the next few years. The key to integrating digital signals onto the typical analog telephone network is to use frequency bands above the $3-\mathrm{kHz}$ bandwidth that is used for voice communications. Voice and digital messages are sent simultaneously and separated at the customer, probably with a single control unit per customer. AMR systems can eventually take advantage of this system for full featured, full-time, two-way communications meter reading services. Although the dial-in system would not be affected by telephone network upgrade to ISDN, current dial-out systems would not work without modification to the interface electronics.

\subsubsection{Dial-In Telephone}

In dial-in (inbound) AMR systems, the communication is initiated by the metering equipment at the customer site via telephone modem. Once a connection is established, two-way communication is usually possible. The meter-reading frequency is controlled by 
scheduling that is downloaded from the central station to the metering equipment during each communication. Some metering equipinent may also initiate a call to respond by exception (e.g., alarm, tamper detection).

Dial-in systems use the telephone company rate structure to their advantage. The monthly fixed charge for local calls, which the customer already pays, covers the AMR system calls. If long distance or intercity tariffs apply, then the customer must be reimbursed by the utility or the utility must use an $\mathbf{8 0 0}$ number. Although rare, there have been a few cases in which the telephone company has charged an extra fee for this service, and all such systems are potentially subject to tariffs.

Because the dial-in equipment acts like a typical analog telephone extension, no additional telephone equipment (e.g., at the telephone company) is necessary for its implementation. This gives it the advaniage of simplicity and relatively low cost. This is traded off against the disadvantage that the utility cannot obtain meter readings on demand. The utility must wait until the next scheduled call-in. However, most dial-in systems have a built-in feature for initiating two-way communications (dial-out), which will allow for an on-demand metering reading or programming modification. Because these dial-out interrogations typically require the customer's phone to ring, they cannot be used except under special circumstances, such as a final read for a terminating customer or a verification re-read. Table 4.2 lists the relative merits of dial-in telephone systems.

An interesting option is t.e use of radio (AM, FM, or pager system) for outgoing messages combined with dial-in telephone for return messages. For example, a dial-in meter could be commanded via radio to call the central station for a special meter read or rate schedule update at times not previously scheduled. Although such an option would add a lot of versatility to the dial-in telephone technology, there is no such commercial product to date.

\subsubsection{Dial-Out Telephone: No-Ring}

In dial-out (outbound) AMR systems, all normal communications are initiated by the central station via telephone modem. Special telephone company equipment is required to connect to metering equipment at the customer site without ringing the customer's telephone. These are interrogate/respond or polled systems, controlled by the central station, although some metering equipment may also respond by exception (e.g., alarm, tamper detection).

In today's dial-out AMR systems, a utility computer modem accesses meters by calling a central office loop access controller. This access controller is the telephone network's basic test device, used to check telephone service by accessing a central office switch through a trunk line, calling a number, and sending tones over the "no-test loop." The controller also suppresses the 
Table 42. Relative Merits of Dial-In Telephone Systems

\begin{tabular}{|c|c|}
\hline es & Disadvantages \\
\hline $\begin{array}{l}\text { Convenient implementation. } \\
\text { Well-suited to low-density systems. } \\
\text { No additional equipment needs to be } \\
\text { installed at the telcs office. } \\
\text { No, or very small, phone tariff charges } \\
\text { (no per-call local charges in most cases). } \\
\text { - Intelligence is decentralized, less chance } \\
\text { for total system shutdown. } \\
\text { - Some systems are extensively field- } \\
\text { proven. } \\
\text { Limited dial-out capability (using "rinz- } \\
\text { wait-ring" or other special tone } \\
\text { protocols). }\end{array}$ & $\begin{array}{l}\text { Many dial-in systems need customer } \\
\text { interface to be polled, or simply cannot } \\
\text { be polled, by the central station to check } \\
\text { operational status. } \\
\text { Not well-suited to interrogate/respond, } \\
\text { or polled, system operation (e.g., real- } \\
\text { time monitoring and control). } \\
\text { More intelligence required at customer } \\
\text { site, may increase overall system cost. } \\
\text { Problematic field-initiated calls may } \\
\text { continue undetected for extended } \\
\text { periods. } \\
\text { May cause interference with customer } \\
\text { phone. }\end{array}$ \\
\hline
\end{tabular}

telephone's ring function or hangs up if the line is busy. It can read meters very well, but it is also the telephone company's most important tool for testing lines, and it can read only one meter at a time. Table 4.3 lists the relative merits of dial-out telephone systems.

American Telephone and Telegraph (AT\&_) has proposed a Utility Telemetry Trunk (UTT) specification for a combination of software and hardware that will allow a utility to access a central or node telephone office switch using ISDN and fiber-optic technology and then using analog technology along the network. This node switch will be able to bypass many central office switch functions and allow meters to be read more simply and quickly, up to 60,000 reads a minute. This specification will be a standard available to all vendors and telephone operating companies. Although ISDN services, which will provide a system for easy data communications using the standard telephone network, have been promised for a number of years, most telephone operating companies will continue as analog systems for several more years.

Dial-out systems require the installation of special switching equipment at the local telephone switch station, necessitating local telephone company involvement. However, no two telephone operating companies approach AMR in quite the same way. Some are strongly supporting AMR, some are experimenting with the service, and others have completely ignored the business area. Most are in a wait-and-see mode because of the rapidly changing telephone 
Table 4.3. Relative Merits of Dial-Out Telephone Systems

\begin{tabular}{|c|c|}
\hline Adva & Disadvantages \\
\hline $\begin{array}{l}\text { Data can be obtained on demand, } \\
\text { providing customer's line is free. } \\
\text { System intelligence is centralized, } \\
\text { possibly resulting in greater economics. } \\
\text { Can be used for limited load } \\
\text { management, remote disconnect and } \\
\text { reconnect, and some customer service } \\
\text { functions. } \\
\text { Is well-suited to large systems where } \\
\text { telco involvement and additional } \\
\text { equipment expenses can be amortized } \\
\text { over a large number of customers. } \\
\text { Some systems are extensively field- } \\
\text { proven. }\end{array}$ & $\begin{array}{l}\text { Additional equipment needed at telco } \\
\text { office leading to increased system } \\
\text { complexity and expense. } \\
\text { - Phone ccinpany tariff charges will be } \\
\text { encountered. } \\
\text { - One, or in large service territories } \\
\text { sometimes more than one, phone } \\
\text { company involvement required; a } \\
\text { complication. } \\
\text { Centralized intelligence incurs greater } \\
\text { risk of total system shutdown. } \\
\text { Technology developments may quickly } \\
\text { render today's telco equipment obsolete. } \\
\text { May cause interference with customer } \\
\text { phone. }\end{array}$ \\
\hline
\end{tabular}

equipment and communications standards. The telephone company involvement will result in a tariff or fee per call. Many utilities are concerned that even though this cost per call may be cost-effective today, the telephone company's future rate structure is out of the utility's control. Large investments in equipment may he jeopardized by future telephone company rate increases.

Although dial-in systems would not be affected by a telephone network upgrade to ISDN, current dial-out systems would not work without modification to their interface electronics. The interface electronics at the meter will have to be compatible with either RS232, X.25, or ISDN. Many utilities are hesitant to install large-scale dial-out systems because of this potential future compatibility problem.

\subsubsection{Dial-Out Telephone: Conventional}

The conventional dial-out telephone system uses a dedicated telephone line and standard telephone modem at the remote terminal unit (RTU) to communicate with a meter. Because the telephone will ring each time the meter is contacted, sharing the AMR line with an existing voice line is not acceptable in most circumstances. Although communication via a dedicated 
telephone line works well, leasing large numbers of lines may be prohibitively costly or may simply be impossible because of limited "extra" lines available in the custorner area. However, this may be a cost-effective technique for those few large commercial or industrial customers who require frequent meter reads.

A no-ring dial-out capability while sharing the AMR line with an existing voice line is possible with the addition of an automatic line-share switch. The line-share switch picks up the line on the first ring (preventing the voice line from ringing), listens for a control code for 4 seconds, and responds to the control code (or absence thereof) by ringing the appropriate voice or meter line. A communications connection can be made with the meter at any time that the telephone is not in use without ringing the customer's telephone.

The line-share switches should include a priority interrupt feature, which automatically disconnects the meter and central station and restores dial tone (typically in less than 2 seconds) if the custom $\mathrm{s}$ picks up the telephone during a meter reading. This is a requirement to allow customer-initiated calls (particularly emergency calls) without interference from the AMR system. If the AMR system central station calls the meter during a customer call, the central station will receive a busy signal, as is typical of any call.

There are two disadvantages to the use of line-share switches. First, each call to the customer is considered a completed call, once the line-share switch picks up the line, even if the customer was not present to receive the call. This may be a problem with people calling long distance to the customer premises. Second, the high cost of quality line-share switches (around $\$ 300$ to $\$ 500$ each) will limit the metering applications for which this option is cost-effective.

\subsection{Long-Range Radio Systems}

AMR systems can use a variety of radio frequency techniques for long-range communications. Advances in radio technologies have dramatically i...proved radio as a reliable, low-cost communications technique. Some oi the radio systems applicable to AMR systems are briefly described in this section. Because of intense competition for available radio frequencies, all the radio techniques except for low-power spread spectrum require an FCC license. Unfortunately, the licensing process is often time-consuming and expensive to obtain and maintain.

\subsubsection{Amplitude-Modulation (AM) Radio}

Modulation techniques allow digital messages to be superimposed on regular analog AM band radio programming material without affecting the reception of the AM programming material. This is a unidirectional communication from the broadcast station to the meters, whicil must then use another return communications path. With appropriate meter addressing, this could be a useful way of forcing dial-in systems to respond on demand. AM radio-based AMR systems have not hac widespread application. 


\subsubsection{Frequency-Modulation (FM) Radio}

FM Subsidiary Communications Authorization (SCA) communication, which has been used primarily for background music (e.g., Muzak ${ }^{\mathrm{TM}}$ ) and specialized communications services (e.g., financial market information, paging services), was recently made available by the FCC for utility company use. As with AM radio, this is a unidirectional communication from the broadcast station to the meters, which must then use another return communications path. With appropriate meter addressing, this could be a useful way of forcing dial-in systems to respond on demand. Although FM SCA radio is used extensively for load control systems, there have not been widespread AMR system applications.

\subsubsection{Ultra-High-Frequency (UHF) Radio}

Utility companies use UHF-band radio channels for two-way voice traffic and for SCADA systems. The frequencies available are very limited, although many utility companies have already licensed channels that may be available for AMR system use. Most utilities want to hold the licensed channels in reserve for future SCADA system applications instead of AMR systems.

\subsubsection{0-MHz Radio}

A 1981 FCC ruling set aside 20 frequency pairs of the $900-\mathrm{MHz}$ region for use by utility companies for general monitoring and control communications, including AMR systems. The FCC specified that equipment would transmit on $928 . \mathrm{XXX} \mathrm{MHz}$ while the return link would be at 952.XXX MHz.

These radio channels are being used extensively for SCADA, distribution automation, and special monitoring and control, but may be too expensive for mass AMR systems. The high equipment costs for separate radio transceivers result from performance specifications that are difficult to achieve with simple electronics.

For AMR system applications, the $900-\mathrm{Mhz}$ radio transceivers, which are essentially limited "line-of-sight" with short range, often employ a cellular design using low-power remote units and relay stations and high-power master stations. Power output of the remote units and relay stations cannot exceed $5 \mathrm{~W}$. The remote units and relay stations are not licensed, but the high powered master stations require an FCC license. Data compression techniques can allow very high-speed two-way data communications. Table 4.4 lists the relative merits of cellular radio systems. 
Table 4.4. Relative Merits of $900-\mathrm{MHz}$ Cellular Radio Systems

\begin{tabular}{|c|c|}
\hline Advantages & Disadvantages \\
\hline $\begin{array}{l}\text { Nearest of all AMR systems to true } \\
\text { "instantaneous" data transfer. } \\
\text { - Data can be returned on demand, at any } \\
\text { time. } \\
\text { - Well-suited to distribution automation } \\
\text { applications including load management, } \\
\text { remote disconnect and reconnect. } \\
\text { - Well-suited for customer service } \\
\text { functions (security, energy management, } \\
\text { customer information). }\end{array}$ & $\begin{array}{l}\text { Most expensive system cost. } \\
\text { - Greatest installation cost. } \\
\text { - Longest installation cycle. } \\
\text { - FCC license required. } \\
\text { - Cellular AMR systems are not mature, } \\
\text { field-proven technologies. }\end{array}$ \\
\hline
\end{tabular}

\subsubsection{0-MHz Spread-Spectrum Radio}

The FCC has set aside the 902- to $928-\mathrm{MHz}$ radio frequency band for use by unlicens ed radio communications techniques, including spread spectrum. Spread spectrum occupies a relatively large portion of the frequency spectrum by using either "frequency hopping" or "pseudo random sequence." Both techniques transmit the data over multiple frequencies at low power. An advantage of the spread-spectrum technique, particularly in a crowded radio spectrum, is that a unit that transmits for only a short time on any one frequency cannot cause much interference on that frequency. Therefore, a large number of such units can communicate independently within the same geographic area and use the same region of the spectrum.

AMR system applications employ a hybrid of short-distance power line carrier communication between an RTU at the customer's site and the nearest distribution transformer, followed by packet radio communications between the distribution transformer and the central station. The packet radio system can be low-powered, spread-spectrum, to avoid FCC license requirements. These are normally interrogate/respond or polled systems, controlled by the central station. Most RTUs may also respond by exception (e.g., alarm, tamper detection). Table 4.5 lists the relative merits of distributed (packet) radio systems.

A recently announced packet radio meter design is capable of communicating via radio directly to a local transceiver. This is a major advancement because it eliminates the power line carrier communications between meter and transceiver. Although the power line carrier works well, its range is limited to the local service transformer, which results in one radio transceiver 
Table 45. Relative Merits of Distributed (Packet) Radio Systems

\begin{tabular}{|l|l|}
\hline \multicolumn{1}{|c|}{ Advantages } & \multicolumn{1}{c|}{ Disadvantages } \\
\hline $\begin{array}{l}\text { Data can be returned on demand, at any } \\
\text { time. }\end{array}$ & $\rightarrow$ Systems are very complex. \\
$\begin{array}{l}\text { Well-suited to distributed automation } \\
\text { applications including load management, } \\
\text { remote disconnect and reconnect. }\end{array}$ & $-\begin{array}{l}\text { Per-point costs higher than telephone- } \\
\text { based systems. }\end{array}$ \\
$\begin{array}{l}\text { Well-suited for customer service } \\
\text { functions (security, energy management, } \\
\text { customer info). }\end{array}$ & $-\begin{array}{l}\text { Installation costs are moderately high. } \\
\text { No FCC license required. }\end{array}$ \\
\end{tabular}

(at approximately $\$ 1000$ each) for each transformer. Although most transformers service up to 10 meters, those with a small number of meters become very expensive metering points. By providing direct radio communications between meter and transceiver, the number of transceivers is determined by the number of nearby meters. For high-density metering, this will significantly reduce the number of required transceivers.

\subsection{Electric Distribution Power Line Carrier and Zero-Crossing}

These two AMR systems use the electric distribution power lines to provide two-way communications between the electric substations and any point on the electric distribution system. Conventional phone or radio- based communications must be used between the central AMR station and the electric substations. These are normally interrogate/respond or polled systems, controlled by the central station. In addition, most RTUs may respond by exception (e.g., alarm, tamper detection). For electricity metering, this communication technique allows the addition a new meter at any point in the distribution system without requiring telephone services or radio coverage. Gas and water metering can be added, but will require a cooperative agreement between multiple utilities. The relative merits of distribution line carrier systems are listed in Table 4.6.

Two distinctly different techniques are used. The first, distribution power line carrier systems, use capacitive coupling to inject $5-\mathrm{kHz}$ to $15-\mathrm{kHz}$ frequency signals on the power lines at each electric substation. Because of carrier signal attenuation caused by distribution system equipment, significant additional equipment may have to be installed throughout the distribution 
Table 4.6. Relative Merits of Distribution Line Carrier Systems

\begin{tabular}{|l|l|}
\hline \multicolumn{1}{|c|}{ Advantages } & \multicolumn{1}{|c|}{ Disadvantages } \\
\hline $\begin{array}{l}\text { Data can be obtained on demand, at any } \\
\text { time. }\end{array}$ & $\begin{array}{l}\text { Communications signal injection } \\
\text { equipment is required for each electric } \\
\text { substation. }\end{array}$ \\
$\begin{array}{l}\text { Adequate for both one- and two-way } \\
\text { communication, for a mixture of AMR } \\
\text { and load control. }\end{array}$ & $-\begin{array}{l}\text { Not well-suited for low-density meter } \\
\text { installation systems. }\end{array}$ \\
$\begin{array}{l}\text { System performance independent of } \\
\text { terrain. }\end{array}$ & $\begin{array}{l}\text { PLC technique may require extensive } \\
\text { Reasonably mature, field-proven } \\
\text { technology. }\end{array}$ \\
& $\begin{array}{l}\text { "tuning". (The zero-crossing technigue } \\
\text { requires no "tuning" equipment.) }\end{array}$ \\
& $\begin{array}{l}\text { Communication rates are moderately } \\
\text { low. }\end{array}$ \\
& $\begin{array}{l}\text { May not be convenient for gas and } \\
\text { water utilities. }\end{array}$ \\
\hline
\end{tabular}

system. This additional equipment is used to "tune" the system (i.e., to account for grounded capacitor banks, above- to below-ground wiring impedance changes, signal nulls from reflection). Frequent retuning may be required if the distribution system configuration undergoes significant changes (e.g., change from overhead to underground lines or switching of feeders). For many systems, the tuning equipment costs will equal or exceed the cost of the substation equipment.

The zero-crossing system has two major advantages. The zero-crossing technique uses electric substation equipment to shift the zero voltage and current-crossing point of the $60-\mathrm{Hz}$ power waveform. This phase shifting results in a communications signal that will pass through all normal distribution system equipment, including transformers. Zero-crossing systems do not require additional tuning equipment. The tradeoff for robust communications is a slow speed, typically 1200 baud. But the second advantage of zero-crossing, the ability to communicate independently and simultaneously on each of the three phases and multiple substations, effectively increases the communications speed by three times the number of substations. Field testing has shown error-free message transmission rates of better than $99 \%$, which also increases the effective communications rate.

Communications via the electric distribution system is an attractive, mature, and fieldproven technology, but the initial equipment investment for each substation of a electrical distribution system is large. These costs may be justified for a high meter density--a large number of installed meters per substation. However, the costs may be prohibitive if the AMR 
system will include only a small number of meters spread throughout the service territory (i.e., serviced by multiple substations).

\subsection{Hybrid AMR Systems}

As expected, an AMR system can use more than a single communications technology. Hybrids of radio and telephone, or telephone and power line carrier, or radio and power line carrier have advantages in some applications. Some AMR systems are designed as hybrids, such as a packet radio system using a power line carrier to communicate between the meter and the local radio transceiver. These mixed technology systems are designed to work together.

Other times, multiple communications technologies are selected to best match the needs of different meter-reading conditions found throughout the service territory. And some AMR systems were assembled using components from different vendors using different technologies, typically because of multiple pilot projects over a period. These mixed systems are generally run separately. It is important to note that at some point the two or more systems will have to be integrated for billing and analysis purposes. 


\subsection{Protocols and Standards}

Despite the increasing use of automation, utilities typically find that the software, hardware, and communication protocols of one manufacturer are incompatible with those of another manufacturer. Most existing AMR systems are not compatible with each other or with other utility SCADA systems. Traditional gas, water, and electric meter manufacturers, along with other industries, continue to introduce new metering automation equipment with incompatible communication protocols.

The situation is not unlike that of the automotive manufacturer General Motors (GM) several years ago. At that time, GM had approximately 40,000 intelligent devices throughout the company; oxily $15 \%$ of those devices could communicate with each other without additional, expensive hardware and software. Equipment compatibility problems accounted for $30 \%$ to $50 \%$ of the total automation cost. Although vendors initially resisted GM's request for total connectivity among systems, GM was a major purchaser of automotive assembly line robots. Because no industry standard protocols were available for guidance, it was not until GM developed a protocol and required compatibility that manufacturers developed such equipment.

The utility situation is similar to the automotive situation. Although there are more utilities than automotive manufacturers, there are still relatively few large utilities. Although each AMR manufacturer has already invested in the development of equipment and protocol, all the manufacturers are clearly interested in providing customers with the products they desire. Many utilities have installed demonstration AMR system projects, but most have indicated an unwillingness to invest in installations with single-source equipment.

Similar to the early automotive industry, no standard has been proposed for the utility automation equipment. The Automatic Meter Reading Association (AMRA) Standard Committee has been working with other standards organization for several years to organize the development of protocols and standards for the utility automation industry. There are similar standards development organizations in Canada, Europe, and Australia. Although all the standards are still in early development, they will eventually offer a utility the ability to mix and match automated meter reading products to suit the utility's specific need. 


\subsection{Data Security}

Tampering and unauthorized access to AMR systems are growing concerns for most utilities and regulatory organizations. The open nature of all the AMR systems provides the opportunity for a homeowner, hacker, or competing utility to access the network, read the data, generate unauthorized commands and/or data, and conduct other illegal and potentially dangerous activities. Such network tampering could result in serious theft, network control, and safety problems.

Because the AMR system must be connected to the home or business to read the meter, physical access to the network is easily available to the potential hacker. Low-cost personal computers and software are sufficient tools for technically sophisticated homeowners to access many of the networks. In addition, sharing network resources with other utilities increases the opportunity for exposing private data and commands to unauthorized sources.

Cryptography is a security measure that prevents access to the data stream and minimizes the potential damage that an intruder could inflict. Cryptographic techniques transform the original message data into coded messages, called cryptograms. Applying cryptographic techniques to the data renders it unintelligible to unauthorized users who access the protected data. However, authorized users, who know the proper code or cipher, can easily translate the cryptograms back to plain text for further processing. 


\subsection{Discussion}

All the AMR technologies are compared in Table 7.1. Presented is a general comparison of the applicability of the technology types to various meter density/terrain installation conditions, utility rate structures and data collection frequencies, and additional services.

The estimated equipment cost for a generic 200-meter system for each AMR technology is also listed in Table 7.1. Note that this cost does not include installation labor. Also, the cost assumes that standard utility meters are already installed and will be converted for use with the AMR system. Because most federal facilities have very few existing meters, a significant additional cost may be associated with initial installation of basic metering equipment before the AMR system can begin.

Handheld computers, with remote meter reading and remote electronic meter reading, introduced automation into the meter reading and billing process, plus access to hard-to-read meters. But these systems still require a person to physically contact each meter or a receptacle linked to a nearby meter.

Mobile radio systems reduce labor requirements and read errors by using low-power radio to communicate directly between a meter and a handheld or van-based computer. Mobile radio systems have the largest number of installed units and have the highest acceptance by utilities. However, they are limited with regard to meter-reading frequency (scheduled monthly reads only) and other advanced metering features.

Dial-in telephone system meters are programmed to periodically call the central station by using a shared customer telephone line. The central station cannot contac: the meter without ringing the customer's telephone. This system raises some privacy issues and limits the meterreading frequency and other advanced metering features requiring communications initiated by the central station.

Conventional dial-out telephone systems with dedicated leased telephone lines are probably the least expensive form of an unrestricted full-time, two-way communications AMR system for a limited number of special customers. Special customers include those with very hard-to-read meters or unique metering requirements (large customers). Some dedicated lines can be avoided by using automatic line-share switches, which connect a shared line to a meter without ringing the customer's telephone. Telephone AMR systems will work with either standard land lines or cellular telephones.

Expansion to a large set of customers will require no-ring dial-out telephone systems. The no-ring dial-out telephone system is dependent on the cooperation of the telephone operating company for access, installation of special equipment at the telephone switch station, and 


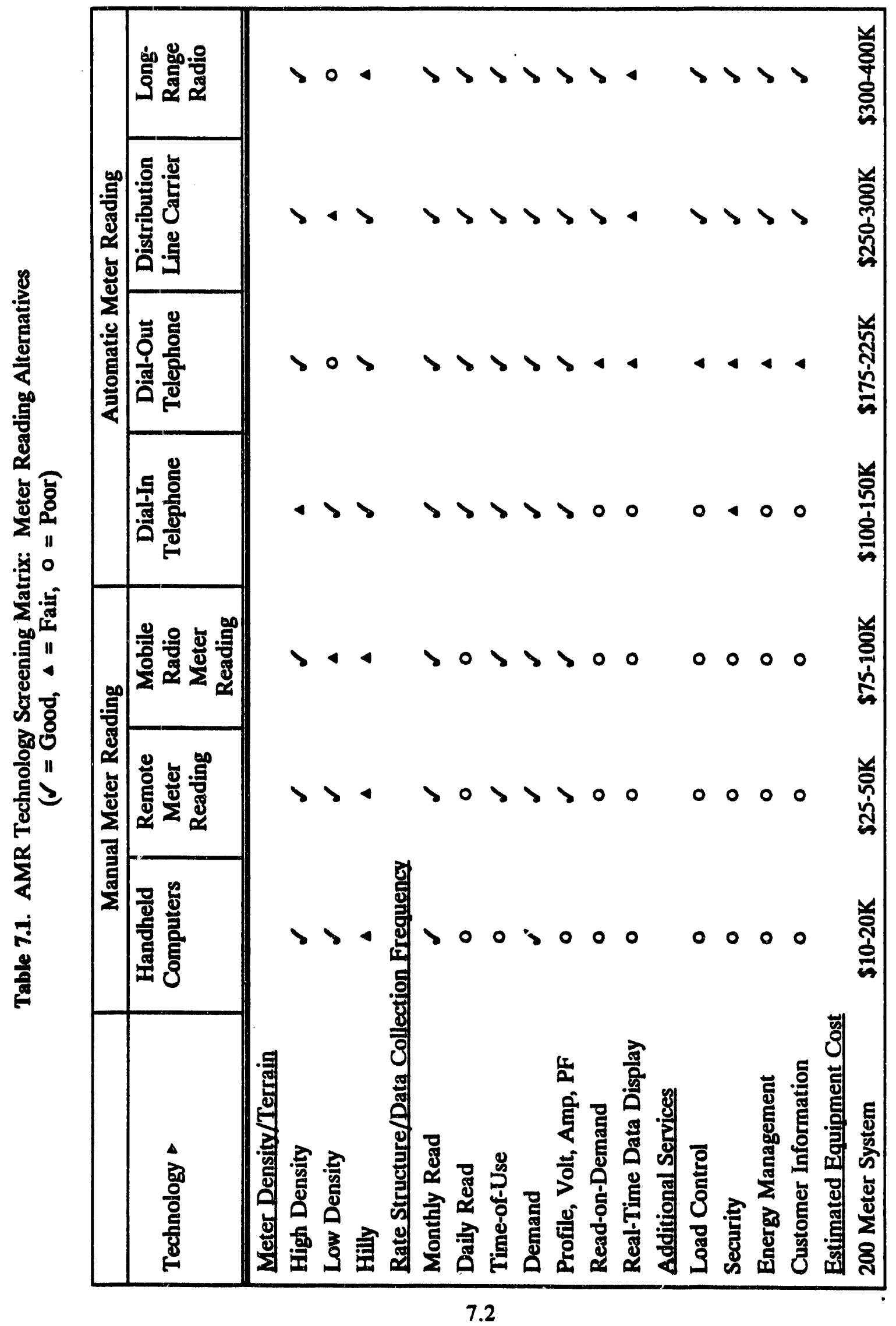


reasonable tariffs. It has also proven to be a difficult telephone number management problem for large systems.

Distribution line carrier (DLC) systems perform well for high-density electric metering and DSM load control. These systems--both power line carrier and zero-crossing techniques that communicate using the electric utility's power distribution system--are independent of the telephone companies and radio frequency availability problems. However, they may be prohibitively expensive for very low-density metering and may be unavailable for some gas and water metering.

Long-range radio, configured as packet transceivers, cellular nodes, or central broadcast towers, can offer the largest range of near real-time meter reading for large metering systems. Both the central and distributed systems typically use a short-range power line carrier to communicate between the meter and the radio transceiver. This is the only technology that can provide unrestricted high-speed, two-way communication with each individual meter of a large system, which may be necessary for additional services such as security, energy management, or customer information. However, the radio equipment required for complete coverage of a large service territory, and its maintenance, is the most expensive of all the systems.

The AMR system equipment manufacturers and the AMR technology offered are listed in the Appendix. The AMR market is not stable; the list of manufacturers will change as new technologies and companies enter the market, existing companies move out of the market, or existing companies merge. Available AMR technologies may change as competing companies license technologies from other companies in order to offer more options.

To date, most of the AMR system installations have been trials and demonstrations. Very few utilities have committed to full-scale implementation of AMR. The reasons include 1) rapidly evolving technologies, 2) lack of standardization between vendors, which results in single-source dependence, 3) relatively high equipment costs, and 4) a very conservative approach toward large-scale changes in existing, proven, meter-reading practices. Table 7.2 lists the number of installed metering units for each AMR technology. Note that the mobile radio technology is the smallest change from existing metering reading practice, is the lowest cost, and has the largest installed base. But off-site meter-reading technology still requires periodic field visits for meter reading, typically as a vehicle-based meter reader system, and is limited to traditional monthly reads. 
Table 72. Number of Installed Metering Units Versus AMR Technology

\begin{tabular}{|l|c|c|c|}
\hline \multicolumn{1}{|c|}{ Technology } & $\begin{array}{c}\text { Number of } \\
\text { Installations }\end{array}$ & $\begin{array}{c}\text { Average } \\
\text { Installation } \\
\text { Size }\end{array}$ & $\begin{array}{c}\text { Total } \\
\text { Units } \\
\text { Installed }\end{array}$ \\
\hline \hline Off-Site (Mobile Radio) & 33 & 23,000 & 750,000 \\
\hline Dial-In Telephone & 50 & 5,500 & 272,000 \\
\hline Dial-Out Telephone & 55 & 4,300 & 235,000 \\
\hline Distribution Line Carrier & 15 & 24,000 & 362,000 \\
\hline $\begin{array}{l}\text { Long-Range Radio (Packet \& } \\
\text { Cellular Telephone) }\end{array}$ & 4 & 1,300 & 5,000 \\
\hline
\end{tabular}

Source: Automatic Meter Reading Association NEWS (1991). 


\subsection{Selecting an Automatic Meter-Reading System}

This report has presented the operating characteristics and relative merits of all the major AMR system technologies in use today. Each technology excels in one or more areas, but each also has a technical weakness or high cost. There is no single "best" AMR system for all applications. Selection of the most appropriate AMR system will require investigation of the characteristics of the service territory to be metered, the number and type of customers to be metered, and the current and future metering requirements.

In Section 8.1, the criteria for choosing an appropriate system are presented. Then, in Section 8.2, two cases exemplify how a "best" AMR system technology is selected.

\subsection{AMR System Selection Criteria}

The first step in selecting an AMR system is to envision the system after it is operational. This vision-defining process involves determining what type of system meets the current and future needs of the installation, defining a preliminary system architecture, and beginning an analysis of the associated costs and benefits. The envisioning process may be the most important phase of an AMR program.

The following questions, plus issues specific to each installation, should be addressed for each AMR system:

- What information do you want the AMR system to provide?

- How often will the meters be read (daily, monthly)?

- What rate structures are used (consumption, TOU, demand, PF)?

- Should the AMR system include all utilities (electricity, gas, water)?

- Should a manual meter-reading capability remain as a backup/system check?

- Is historical profile data recording required?

- Is more detailed electrical information necessary (e.g., volts, amperes, PF)?

- Will some meters be read more frequently than others to determine system loading (on demand or real-time load management)?

- Will meter-reading data be shared among several utility users? 
- Will the AMR system collect information other than meter reads (SCADA, DA, DSM, billing, security)?

- Will DSM load management be added in the future?

- Should the AMR system combine both meter readings and load management?

- How will the AMR system interface 'with existing and future billing systems?

- How will the AMR system interface with future EMC/SCADA systems?

One special consideration for federal facilities is that most buildings do not have any installed metering and were not designed for the installation of metering. Most AMR systems automatically assume that a utility has existing metering that will be adapted. The installation of basic metering equipment that is compatible with an AMR system will be a significant additional cost. Gas and water metering options are limited to installation of standard metering with electronic meter-reading equipment.

For electricity metering, an option is to use a metering system that can be installed without major rewiring of the building service entrance. Split-core current transformers, clamp-on potential transformers, and the capability for combining multiple service entrances into a single metering point are features that will reduce the overall metering cost.

\subsection{System Selection Case Studies}

As an example, a "best" AMR system technology is selected for two different cases that are representative of many federal facilities. Table 8.1 presents site characteristics, AMR system specifications, and selection implications that are common to both Case 1 and Case 2.

\subsubsection{Case 1 Specifications and AMR Technology Selection}

Special AMR system assumptions for Case 1 are presented in Table 8.2. Case 1 is a minimum configuration, with a small number (100 to 500) of basic monthly-read meters. $A$ dialin telephone technology is probably the most appropriate AMR system for Case 1. The dial-in telephone technology has the lowest first cost for equipment and requires the least equipment maintenance, while allowing for sophisticated metering. The dial-in system can be supplemented with limited dial-out for special meters that require frequent and/or unscheduled reads. The dial-out meters will either require a dedicated telephone line or can share a voice line using a special switch that allows calling the meter without ringing the customer's telephone.

\subsubsection{Case 2 Specifications and AMR Technology Selection}

Special AMR system assumptions for Case 2 are presented in Table 8.3. Case 2 is a full AMR system implementation, with a large number $(1,000$ to 5,000) of meters and DSM load control features. A distribution line carrier $(D L C)$ system using the zero-crossing technique is probably the most appropriate AMR system for Case 2. The distribution line carrier technology 
Table 8.1. AMR System Assumptions Common to Both Case 1 and Case 2

\begin{tabular}{|c|c|}
\hline Site Characteristic/AMR Specification & Selection Implication \\
\hline $\begin{array}{l}\text { Most of the buildings do not have } \\
\text { existing met/aring, and were not designed } \\
\text { for installation of conventional metering. }\end{array}$ & $\begin{array}{l}\text { For electric metering it may be convenient to } \\
\text { install split-core current and clamp-on } \\
\text { potential transformers instead of } \\
\text { conventional metering. For gas and water } \\
\text { metering, basic metering will have to be } \\
\text { installed before an AMR system can be } \\
\text { implemented. This new meter installation } \\
\text { requirement will result in an AMR system } \\
\text { cost that is higher than for commercial } \\
\text { utilities with existing metering. }\end{array}$ \\
\hline $\begin{array}{l}\text { The site hus an old analog telephone } \\
\text { system and central station that needs } \\
\text { maintenance or upgrade, or the site } \\
\text { does not own the telephone central } \\
\text { station. }\end{array}$ & $\begin{array}{l}\text { Dial-out telephone systems may not be a } \\
\text { option because the central station equipment } \\
\text { is not compatible with the old telephore } \\
\text { switch equipment or the site does not control } \\
\text { the telephone central stavion. }\end{array}$ \\
\hline $\begin{array}{l}\text { New telephone lines are not available in } \\
\text { many buildings. }\end{array}$ & $\begin{array}{l}\text { The addition of dedirated telephone linis } \\
\text { may not be an opticn, whick. linits dial-out } \\
\text { telepl. ne system fenetration. }\end{array}$ \\
\hline $\begin{array}{l}\text { The system should have an option fol } \\
\text { reading of gas ard water meters. }\end{array}$ & $\begin{array}{l}\text { The AMR equipment should have } 2-4 \\
\text { recording channels which are compatible with } \\
\text { elect ric, water, and gas meters. Typical } \\
\text { AMR systems are targeted for a single } \\
\text { utility. }\end{array}$ \\
\hline $\begin{array}{l}\text { Some of the meters, and therefore the } \\
\text { data collection system, should be } \\
\text { capable of recording demand profile } \\
\text { (time series) data. }\end{array}$ & $\begin{array}{l}\text { Other advanced rate structure ard data } \\
\text { collection frequency features may a'so be } \\
\text { useful, but are not necessary. These meters } \\
\text { are a very important tool for energy } \\
\text { management. }\end{array}$ \\
\hline $\begin{array}{l}\text { The AMR system should be compatible } \\
\text { with existing or planned EMCS/SCADA } \\
\text { systems. }\end{array}$ & $\begin{array}{l}\text { The lack of industry standards for } \\
\text { communications, electrical and hardware } \\
\text { protocol has prevented this compatibility for } \\
\text { both multiple vendors of AMR systems and a } \\
\text { single vendor which supplies both AMR and } \\
\text { EMCS/SCADA systems. }\end{array}$ \\
\hline $\begin{array}{l}\text { The site has a very limited maintenance } \\
\text { staff. }\end{array}$ & $\begin{array}{l}\text { New, sophisticated, distributed, equipment } \\
\text { must be minimized. Or, the maintenance of } \\
\text { the new equiprnent must be contracted. }\end{array}$ \\
\hline $\begin{array}{l}\text { There is a limited AMR system } \\
\text { operating staff and tight budget. }\end{array}$ & $\begin{array}{l}\text { First cost will drive much of the AMR } \\
\text { system selection. It is very important that } \\
\text { complete technical metering specifications be } \\
\text { developed to prevent installalion of a system } \\
\text { that soon becomes obsolete. }\end{array}$ \\
\hline
\end{tabular}


Table 82. Special AMR System Assumptions for Case 1

\begin{tabular}{|l|l|}
\hline Site Characteristic/AMR Specification & \multicolumn{1}{|c|}{ Selection Implication } \\
\hline $\begin{array}{l}\text { A relatively small number of meter } \\
\text { installations (100 to } 500 \text { meters) are } \\
\text { spread throughout the site. }\end{array}$ & $\begin{array}{l}\text { The first meters will be for reimbursable } \\
\text { customers, only some of which are already } \\
\text { metered. This is a low-density system. }\end{array}$ \\
\hline $\begin{array}{l}\text { DSM load control and other additional } \\
\text { services are not required capabilities. }\end{array}$ & $\begin{array}{l}\text { Continuous, near real-time communication is } \\
\text { not required. }\end{array}$ \\
\hline
\end{tabular}

Table 83. Special AMR System Assumptions for Case 2

\begin{tabular}{|l|l|}
\hline Site Characteristic/AMR Specification & \multicolumn{1}{|c|}{ Selection Implication } \\
\hline $\begin{array}{l}\text { The long-term plan is to meter all of the } \\
\text { buildings, electrical substations, and } \\
\text { several intermediate distribution points } \\
\text { on the facility (1,000 to 5,000 meters). }\end{array}$ & $\begin{array}{l}\text { Similar to Case 1, the AMR system will } \\
\text { initially have a small number of meters, } \\
\text { mainly reimbursable customers, but the } \\
\text { system must be designed for easy growth. } \\
\text { This is a high-density system. }\end{array}$ \\
\hline $\begin{array}{l}\text { DSM load control is a requirement as } \\
\text { part of an overall energy conservation } \\
\text { plan. Other additional services are not } \\
\text { required capabilities. }\end{array}$ & $\begin{array}{l}\text { ON and OFF command of a large number of } \\
\text { load control devices must be available on } \\
\text { short notice. Two-way communications is } \\
\text { preferable to verify operation of the load } \\
\text { control devices. }\end{array}$ \\
\hline
\end{tabular}

has a high first cost for equipment, but provides a simple growth path for a large number of meters. The zero-crossing technique minimizes equipment maintenance because the only communications equipment is located in the electrical substations. DSM load control of electrical devices, with full two-way communications and tamper detection, is easily implemented. The distribution line carrier system can be supplemented with limited dial-out meters for special meters that do not have access to electric power and therefore no communications. The dial-out meters will require either a dedicated telephone line or a shared voice line using a special switch that allows calling the meter without ringing the customer's telephone.

\subsection{Future Trends}

The communications technologies are evolving rapidly, with new product announcements weekly. However, care must be taken because many of these new product announcements are 
Ior "future" products, not necessarily fully functional, field-tested, production line products. A recently announced modified packet radio technique (long-range radio) includes a meter design that can communicate via radio directly with a local transceiver. Existing designs require a PLC to make this communications link. But the PLC range is limited to the local service transformer. This advancement will make packet radio techniques more cost-effective, and makes this technology a potential alternative to the zero-crossing DLC technology selected for Case 2.

The full power of AMR systems will be realized with the installation of continuous realtime communications and electronics that allows a wider range of metering and control functions. More sophisticated metering accommodates a variety of rate structures and provides more detailed load evaluation and power quality (volt, ampere, PF) information--in real time. Control functions allows intelligent DSM load control with the feedback (two-way communications) necessary to ensure that the load control is working and providing the intended demand savings. Use of these new features, which were not traditionally part of meter reading and previously required dedicated and expensive systems, will justify AMR system costs. 


\subsection{References}

Automatic Meter Reading Association NEWS. January 1991. "After a rough patch, AMR is taking off." 4(1):pullout section.

Dulabaum, M. July 1992. "Handhelds Offer Utilities Migration Strategy." Automatic Meter Reading Association NEWS 5(6):1,7.

Scott, D.R. January 1992. "The Evolution of Automatic Meter Reading." Automatic Meter Reading Association NEWS 5(1):1,6-7. 


\section{Appendix}

\section{AMR Equipment and Manufacturers}




\section{Appendix}

\section{AMR Equipment and Manufacturers}

A list of the AMR system equipment manufacturers, as well as the AMR technology offered, is presented in this Appendix. The AMR market is not stable, and the list of manufacturers is a moving target as new technologies and companies enter the market, existing companies move out of the market, or existing companies merge. The AMR technologies offered may also change as companies license technologies from other companies in order to offer more options.

A few words of explanation regarding notes in Table A.1. An "option" under the Dial-In Telephone column indicates that the meter can call into a central station by exception for special circumstances, such as tamper or leak detection. The standard Dial-Out Telephone indicates no-ring by using special equipment at the telephone company's central switch station. An "option" under the Dial-Out Telephone column indicates that the meter can be called by the central station, but it will require ringing the customer's telephone. A "dedicated line" under the Dial-Out Telephone column indicates that the AMR system requires dedicated telephone lines for each meter.

The Distribution Line Carrier column includes both "power line carrier" and "zero-crossing" techniques, as described in Section 4.5 of this report. The "PLC" in the Long-Range Radio column indicates that the system uses a combination of short-range power line carrier to communicate between the meter and a radio transceiver, and then radio to communicate to the central station. 


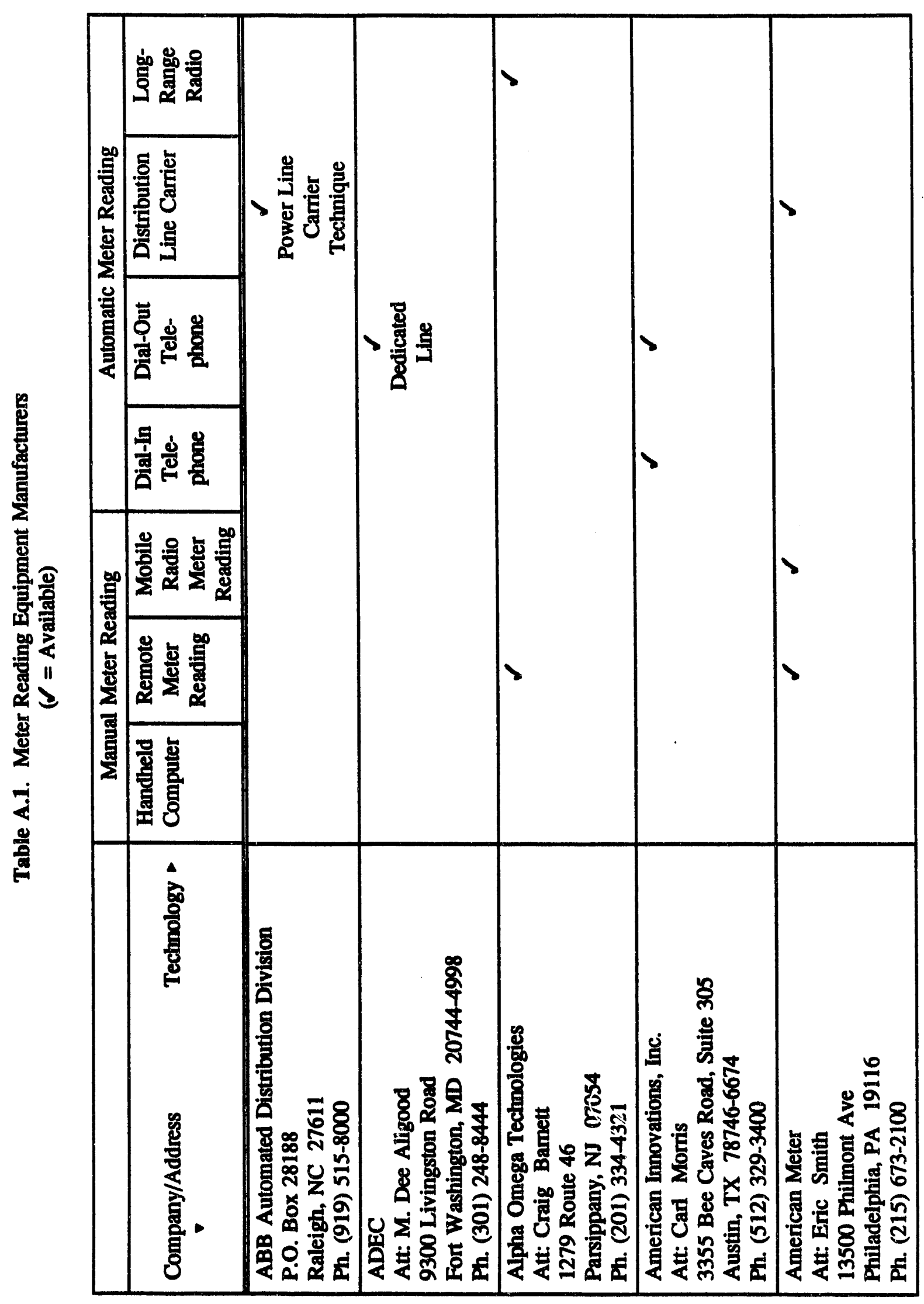

A. 2 


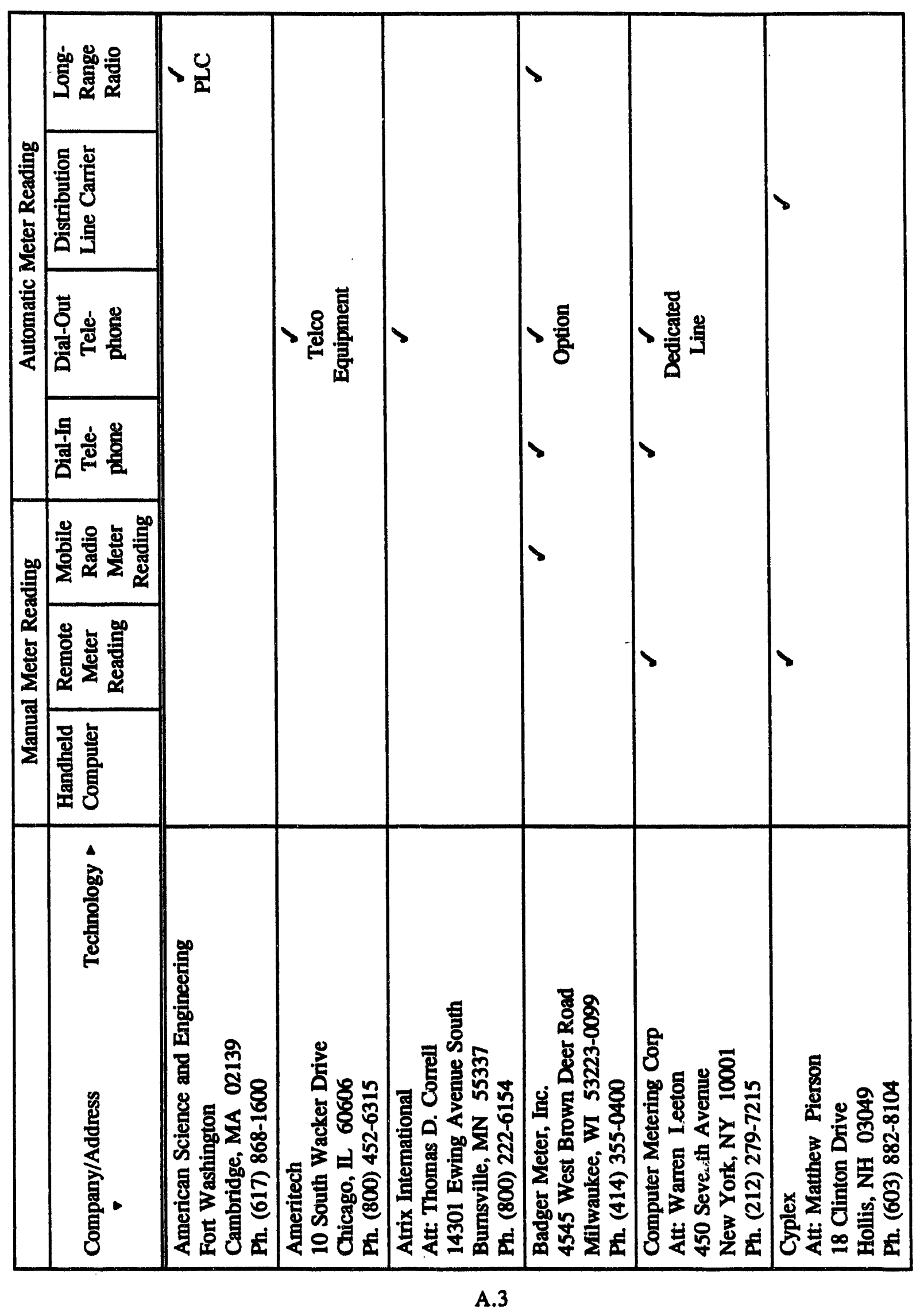




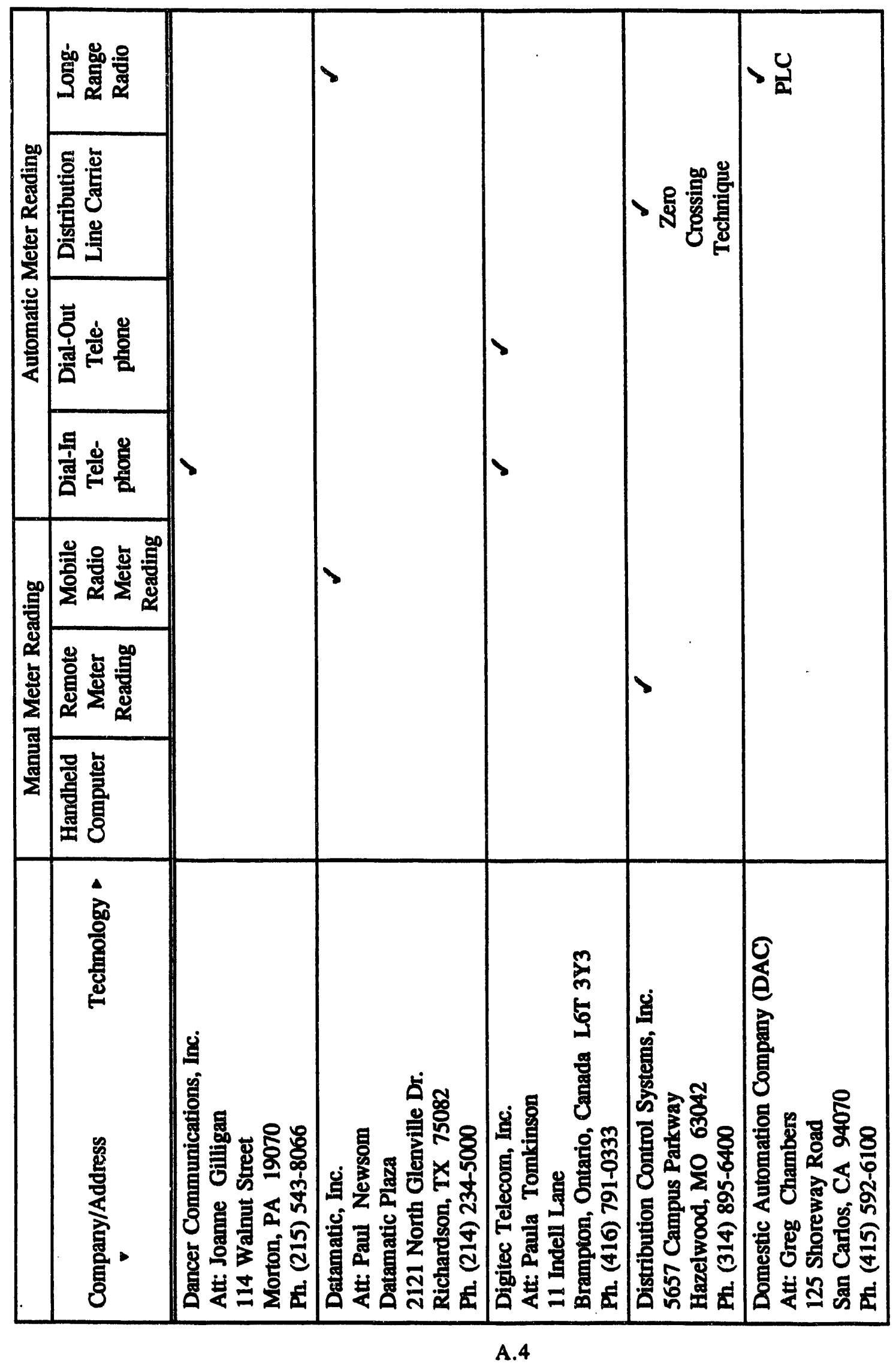




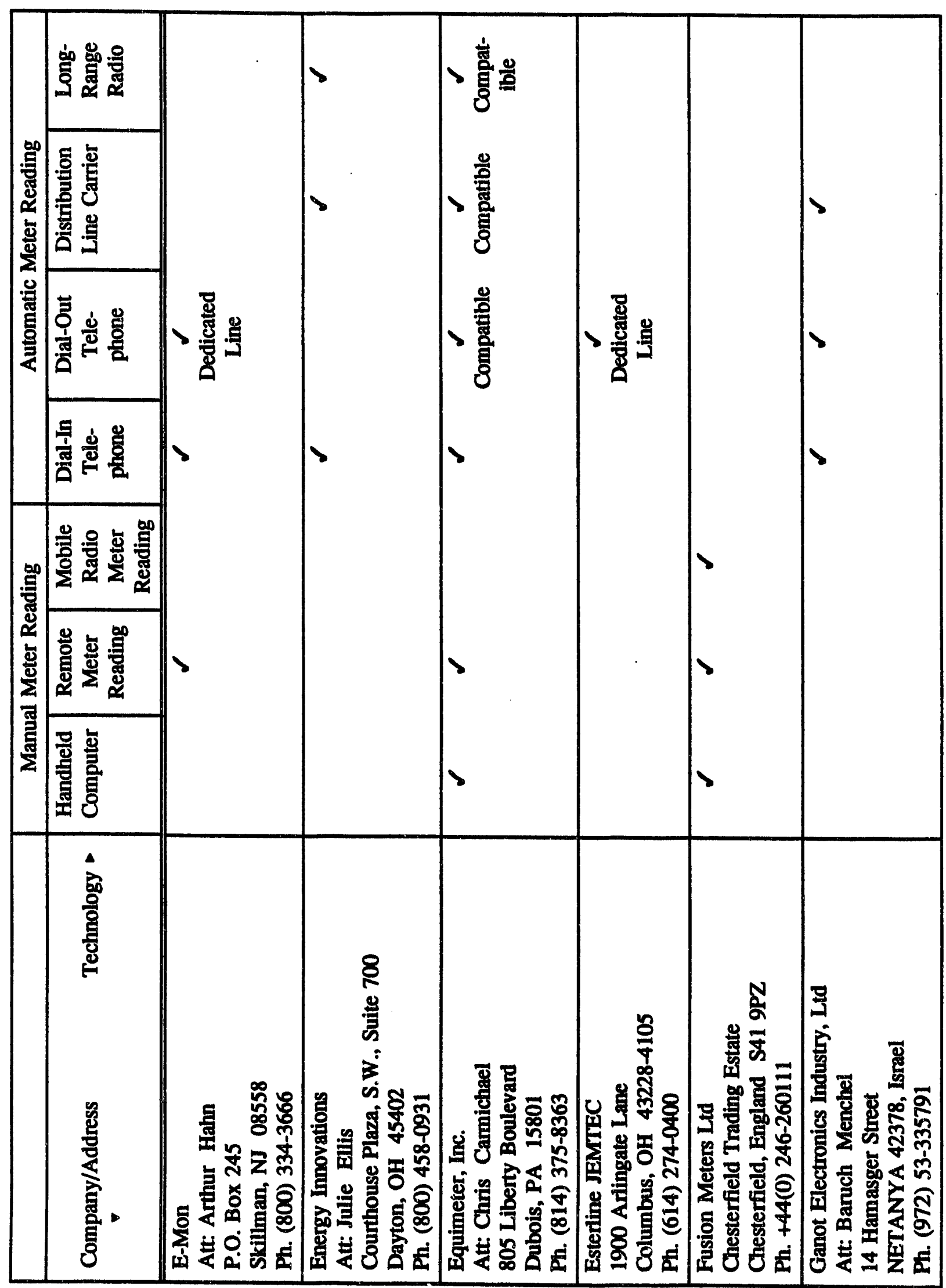

A. 5 


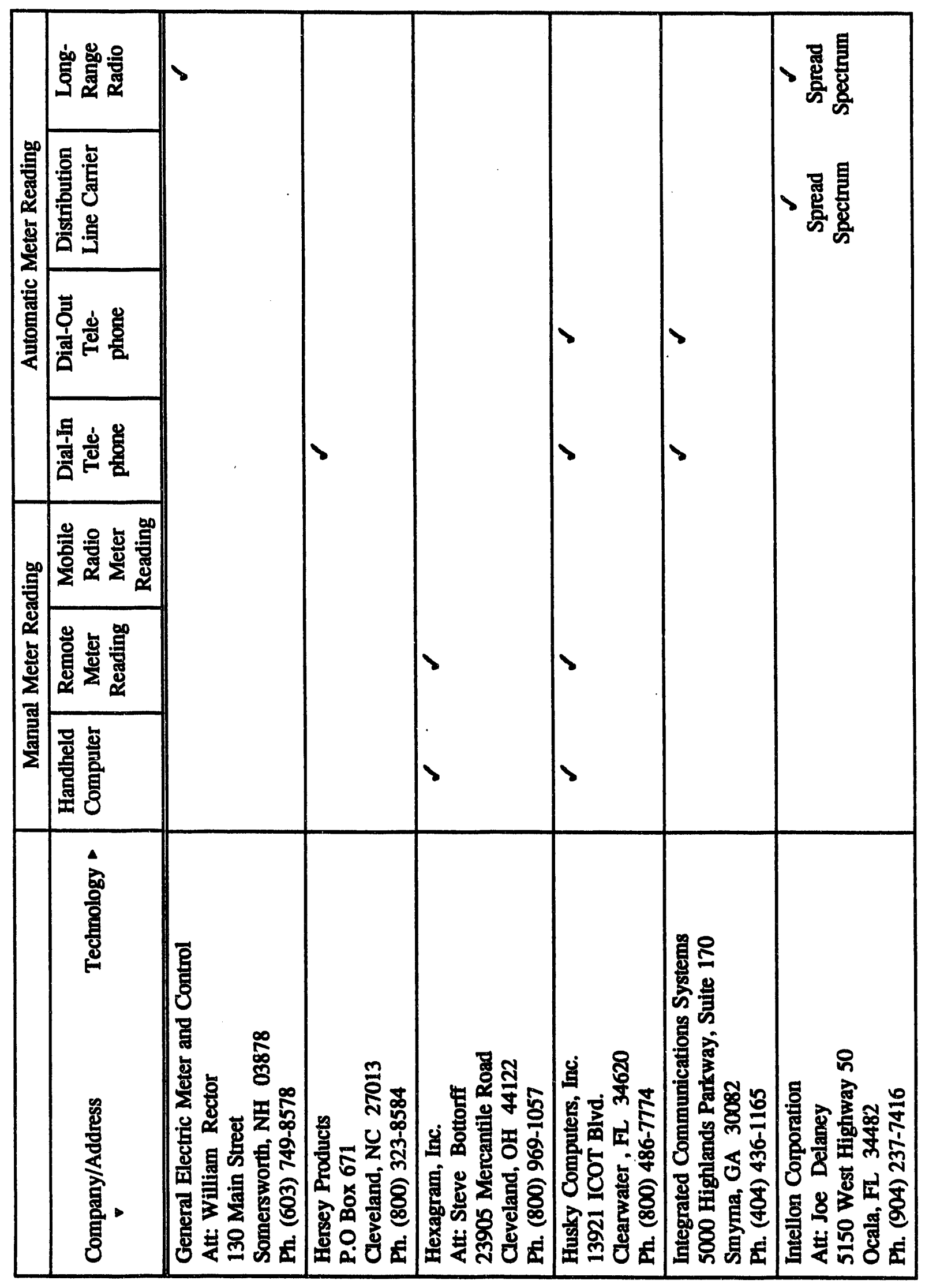

A. 6 


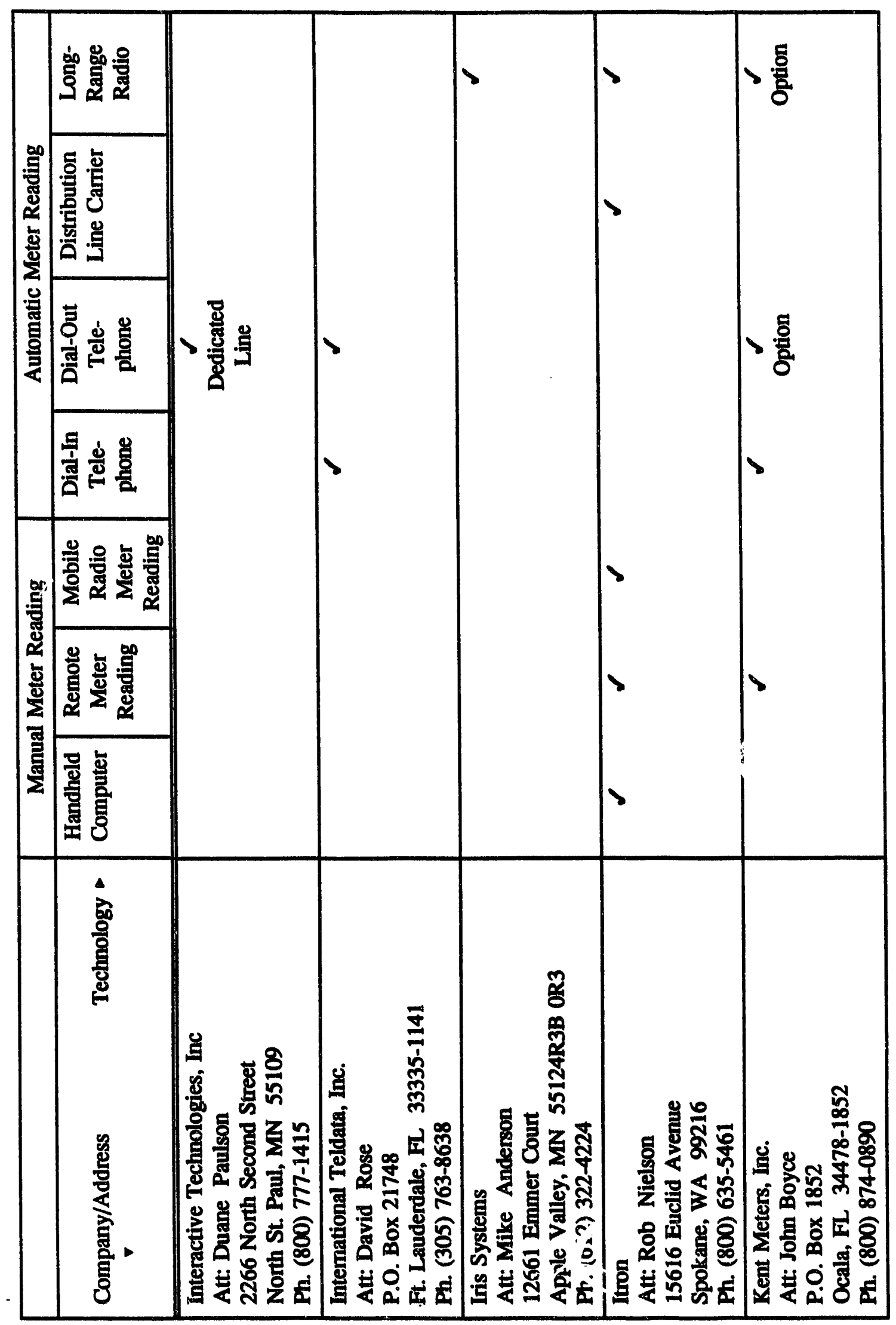

A. 7 


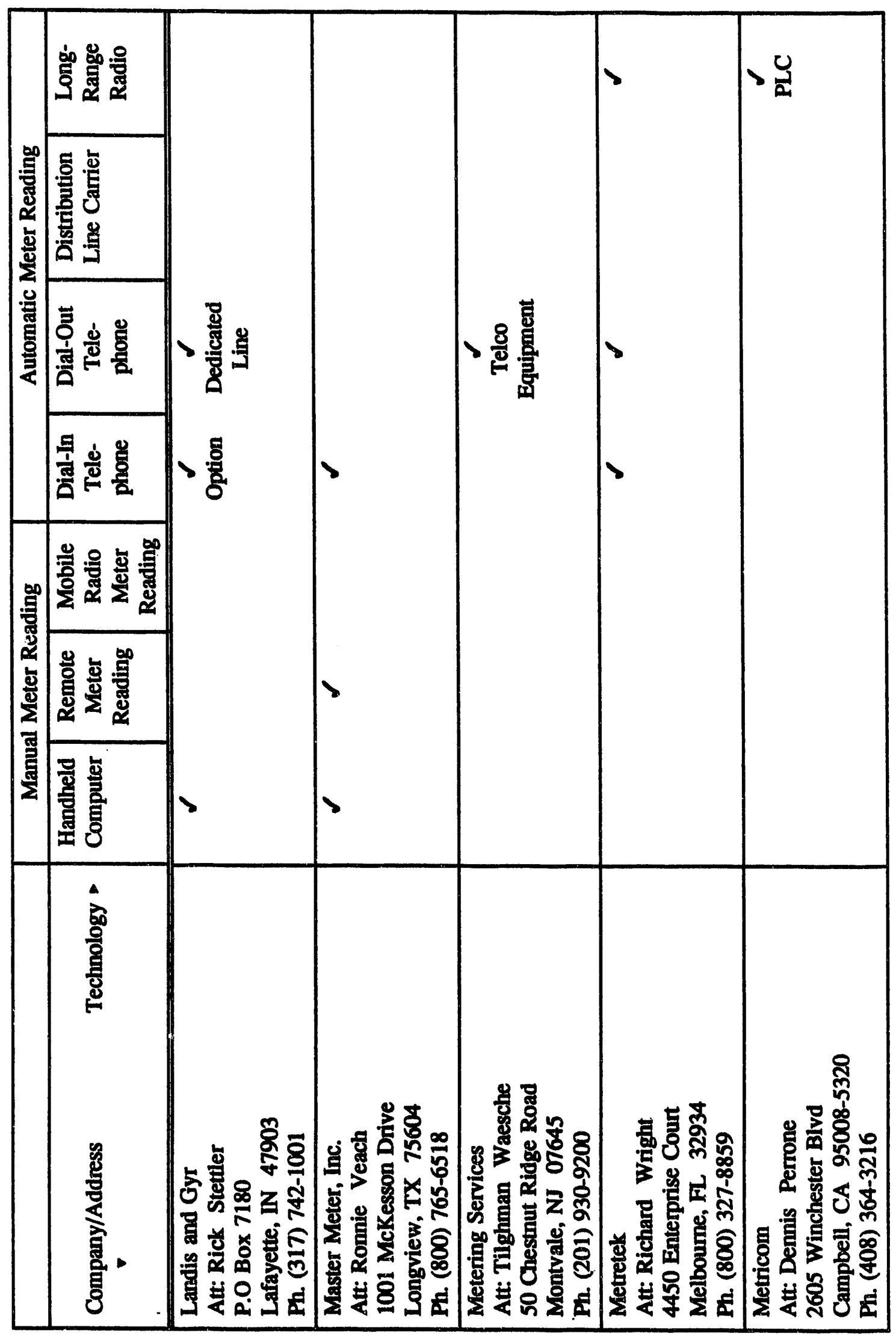

A. 8 


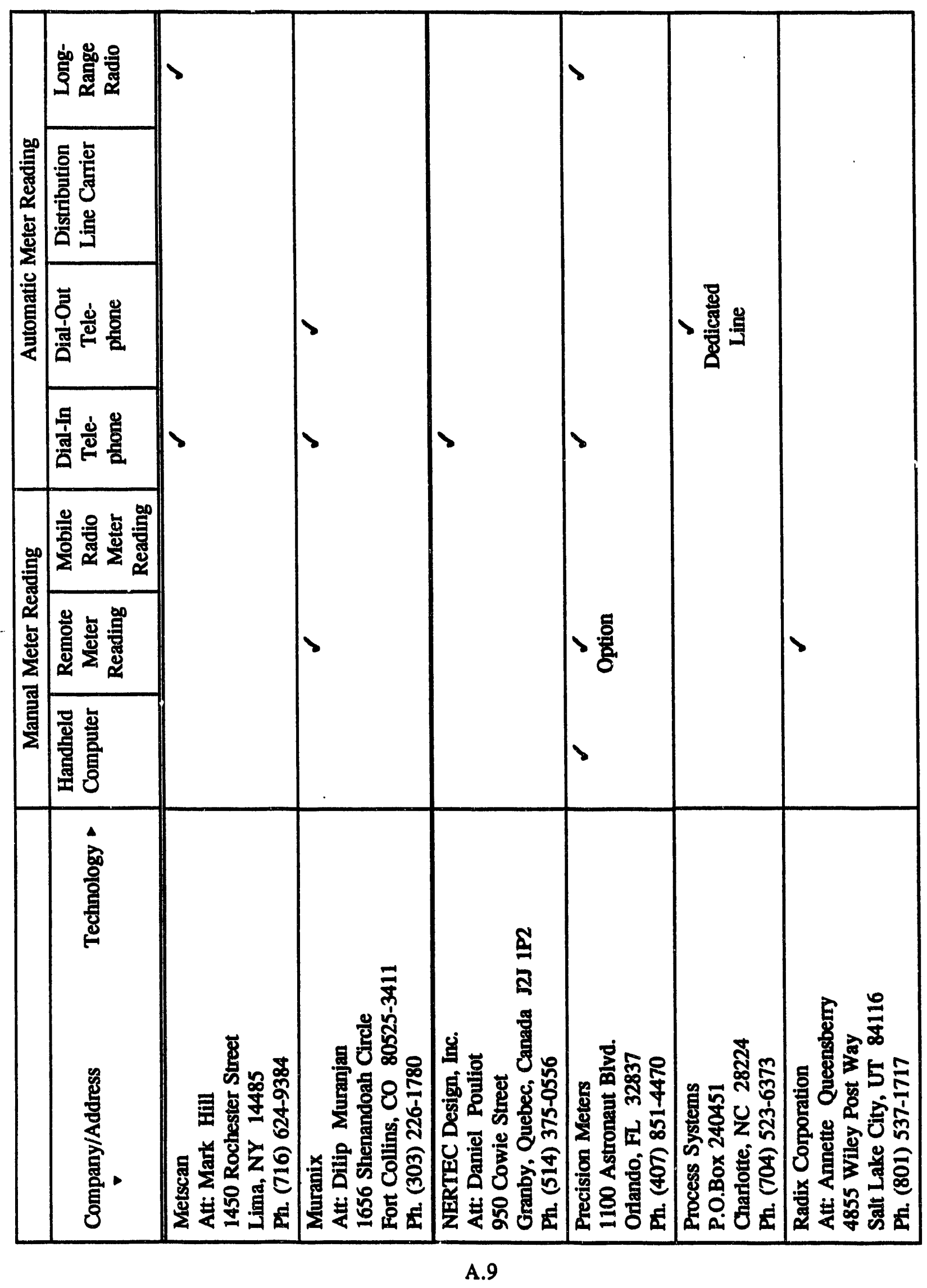




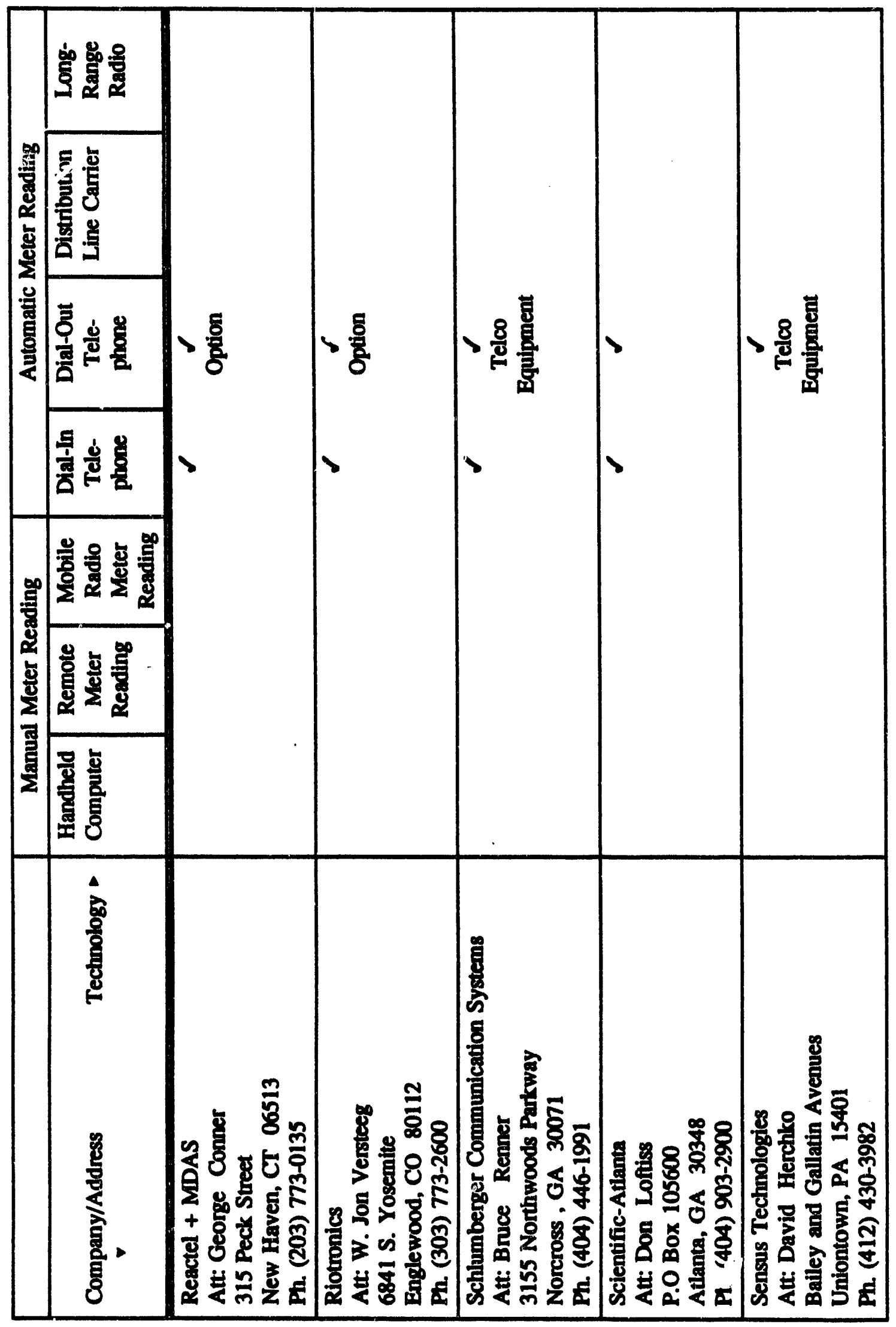

A. 10 


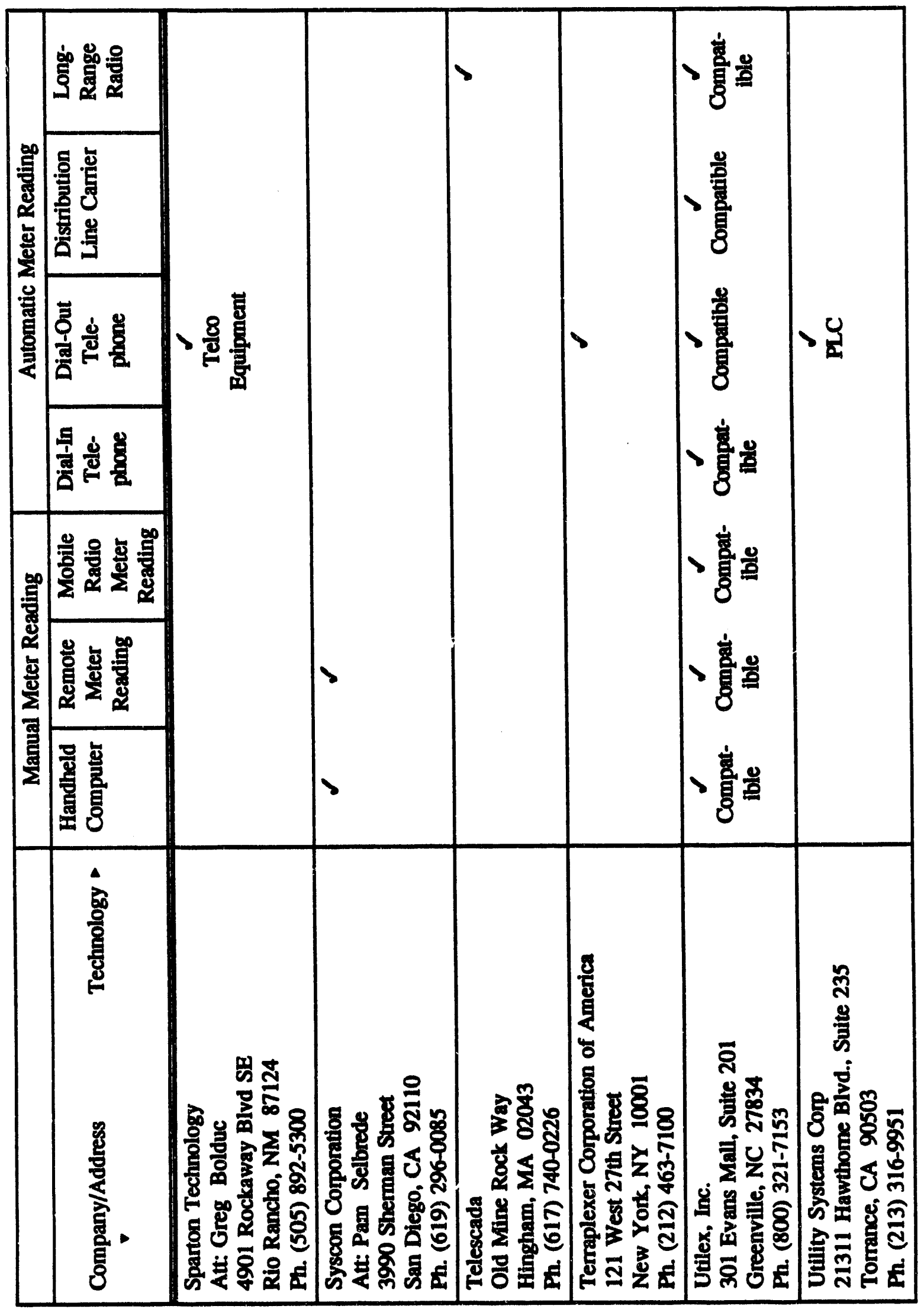

A. 11 


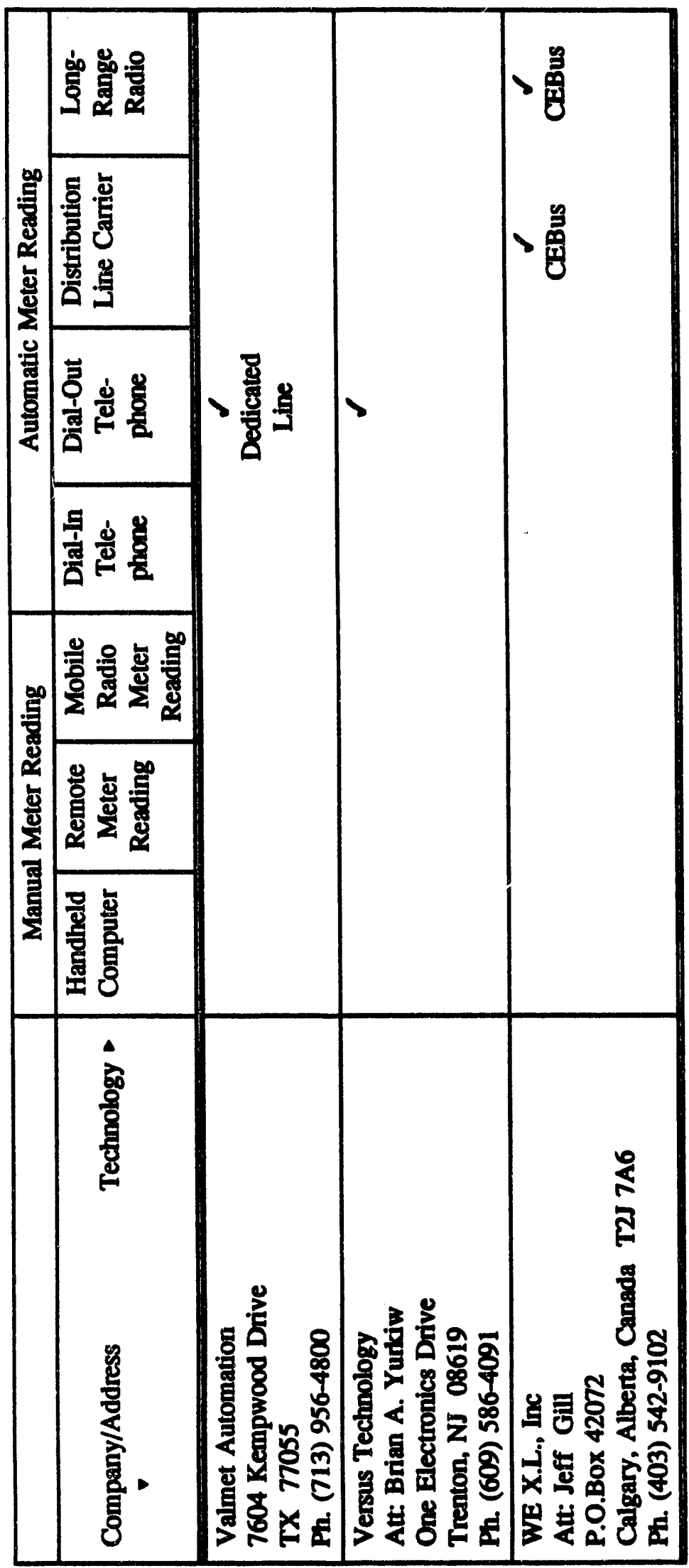

A. 12 


\section{Distribution}

No. of

Copies

Offsite

2 DOE/Office of Scientific and Technical Communication

2 A. Gillespie

Headquarters Forces Command

FCEN-RDF

Building 200

Fort McPherson, GA $30330-6000$

2 B. Starling

U.S. Army Corps of Engineers

Huntsville Division

CEHND/ED/ME

P.O. Box 1600

Huntsville, AL 35807

2 J. B. Paton

Office of the Secretary of Defense

DASD (L) EP

The Pentagon

Washington, DC 20301-8000

K. D. Devine

Federal Energy Management Program

U.S. Department of Energy

CE-10.1

6A-034/FORS

1000 Independence Avenue SW

Washington, DC 20585
No. of

Copies

Onsite

Department of Energy Richland Field Office

D. R. Segna

140 Pacific Northwest Laboratory

R. Bartlett

D. J. Coomes (2)

A. J. Currie

J. W. Currie

D. L. Dixon

G. B. Parker

R. W. Reilly

W. F. Sandusky

R. F. Szydlowski (125)

Publishing Coordination

Technical Report Files (5) 

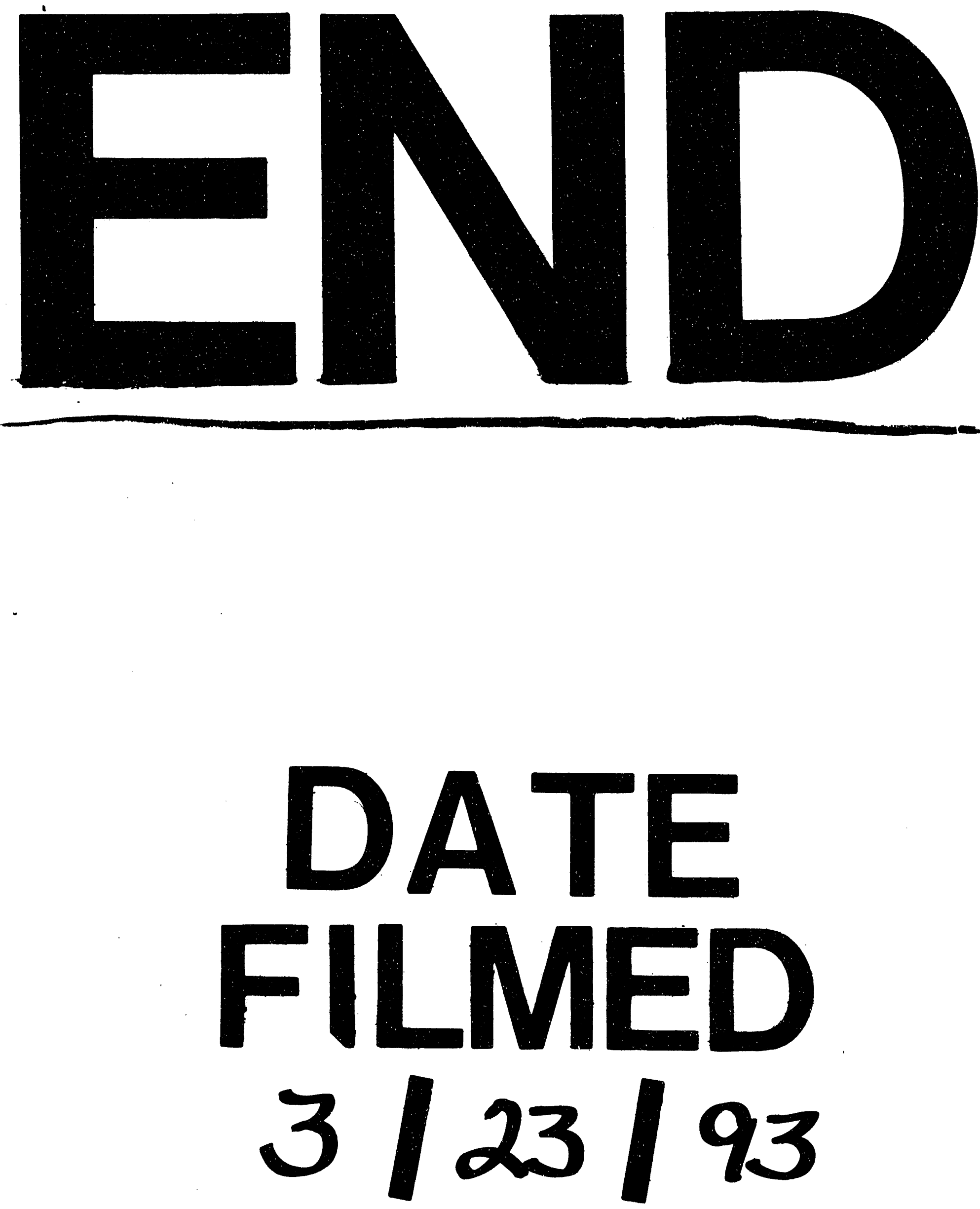
